\title{
1 NE Atlantic continental slope stability from a numerical modeling 2 perspective
}

3

4 Bellwald, B. ${ }^{12^{*}}$, Urlaub, M. ${ }^{3}$, Hjelstuen, B.O. ${ }^{1}$, Sejrup, H.P. ${ }^{1}$, Sørensen, M.B. ${ }^{1}$, Forsberg, C.F. ${ }^{4}$, 5 Vanneste, $\mathrm{M}^{4}{ }^{4}$

$6 \quad{ }^{1}$ Department of Earth Science, University of Bergen, Bergen, Norway

$7 \quad{ }^{2}$ Now at: Volcanic Basin Petroleum Research (VBPR) AS, Oslo, Norway

$8 \quad{ }^{3}$ GEOMAR Helmholtz Centre for Ocean Research Kiel, Kiel, Germany

$9 \quad{ }^{4}$ Norwegian Geotechnical Institute (NGI), Oslo, Norway

10 *benjamin@vbpr.no 


\section{Abstract}

Trough mouth fans are environments characterized by high sediment supply during glacial stages and the occurrence of large-scale instabilities. The geological record indicates that several of these environments have failed repeatedly resulting in large submarine landslides. The roles of sedimentation rate, weak layers, glacial loading and unloading as well as seismic activity on triggering megaslides in trough-mouth-fan systems is still unclear. A better understanding of the preconditioning factors, triggers and consequences of these landslides is crucial due to the hazard they pose to coastal communities and offshore industries.

In this paper, we focus on the North Sea Trough Mouth Fan, which is the result of massive glacial sediment input delivered to the shelf edge through the Norwegian Channel, southeast Nordic Seas margin. The Tampen Slide, one of several large paleo-landslides that have happened within the North Sea Trough Mouth Fan, took place at c. $130 \mathrm{ka}$ (end of MIS 6), and removed an estimated $1800 \mathrm{~km}^{3}$ of sediment.

Here, we use boundary conditions from the Tampen Slide and 2D Finite Element Modeling (Abaqus software from Simulia) to evaluate the effects of variations in sedimentation rates as well as sediment properties on the generation of excess pore pressure, fluid flow, and slope stability along the axis of the trough-mouth-fan system. The model domain, $40 \mathrm{~km}$ in length and $2 \mathrm{~km}$ in height, is dominated by glacigenic debris flows and glacimarine sediment deposits. We use geotechnical data measured on samples of glacigenic and glacimarine sediment deposits from the nearby Ormen Lange gas field area to constrain the model. We evaluate the stability of the slope under various scenarios, including constant sediment loading, episodic changes in sedimentation rates and abrupt pulses in sediment delivery for a $61 \mathrm{kyr}$ period (MIS 6). The models show that increased sedimentation rates during glacial stages do not generate sufficient excess pore pressure to set off a landslide. Furthermore, the simulated overpressures for the different sedimentation scenarios do not significantly differ at the end of the model runs. The results also highlight the importance of a basal glacimarine sediment layer underneath the rapidlydeposited sediments for the build-up of overpressure. Consequently, this glacimarine sediment layer has the inherited potential to act as a weak layer facilitating instability. However, as overpressure due to 
sediment deposition alone does not result in slope failure, we couple the preconditioned slope with earthquake ground shaking. Based on attenuation models, an earthquake of approximately M6.9 or larger at a short distance from the Tampen Slide headwall could have triggered the landslide. Therefore, we suggest glacial sedimentation and a glacimarine sediment layer to represent preconditioning factors, and seismic shaking as the final trigger mechanism for the Tampen Slide, i.e. similar to the situation that lead to the development of the Storegga Slide in the same area.

45 Keywords: North Sea Trough Mouth Fan - Tampen Slide - Slope stability - Overpressure - Trigger mechanism - Earthquake - Quaternary - Glaciation - North Atlantic - Glacial geomorphology 


\section{Introduction}

Evidence of submarine landslides is found both on low-latitude unglaciated and high-latitude (formerly) glacial-dominated continental margins (e.g. Canals et al., 2004). The largest submarine landslides, e.g. the Storegga Slide, tend to occur on continental slopes with remarkably low gradients $\left(<2^{\circ}\right)$. Despite this low dip, the remobilized slide masses runout over distances of several hundreds of kilometers (Hampton et al., 1996). Submarine landslides often develop as retrogressive translational failures, characterized by bedding-parallel glide planes that are separated by distinct escarpments (Hampton et al., 1996; Masson et al., 2010). The gravitational load and generation of overpressure linked to the rapid deposition of glacigenic debris flows (GDFs), plumite deposits and (glaci-)marine sediments seems to play a significant role for the initiation of large submarine landslides on glaciated margins (Bryn et al., 2005; Tripsanas et al., 2008; L'Heureux et al., 2013). Differences in the strength behavior of marine clays and glacial clays are a key aspect for the development of these failures (Kvalstad et al., 2005b).

Due to their potential for seafloor infrastructure damage and tsunami generation, submarine landslides may have a significant socio-economic impact (e.g. Pope et al., 2017). High sedimentation rates, changing sea levels, gas hydrate dissociation and earthquake shaking are frequently discussed as processes that affect slope stability in the submarine environment (e.g. Leynaud et al., 2009). The preconditioning and trigger mechanisms are, however, not always easy to establish (Masson et al., 2010). It is, however, essential for geohazard and risk assessments to understand and distinguish between preconditioning factors and factors that trigger slope failure, as well as understanding the potential consequences. Overpressure is generally considered as a key aspect in most - if not all - preconditioning factors (Vanneste et al., 2014).

Sediment accumulation can outpace the dissipation of pore fluids if rates are high and/or permeability is low. Overpressure, here defined as pore pressure in excess of hydrostatic pressure, reduces the effective stress in the sediments. Overpressure can exist in deep and shallow formations and it most likely occurs where fine-grained sediments having low-permeability $\left(<10^{-16} \mathrm{~m}^{2}\right)$ inhibit pore fluid migration or at locations affected by large forcing mechanisms, such as rapid sediment deposition (Swarbrick and Osborne, 1998; Flemings et al., 2008; Scheider et al., 2009; Dugan and Sheahan, 2012). 
Large-scale slope failures have happened in regions where sedimentation rates are high (McAdoo et al., 2000; Urgeles and Camerlenghi, 2013). Having an important role in the pre-conditioning of subaquatic slopes, rapid sedimentation can set the conditions for the occurrence and volumes of large submarine mass movements (Masson et al., 2006; Dugan and Sheahan, 2012; Stoecklin et al., 2017). Numerical modeling indicates that rapid and prolonged sediment delivery from rivers or ice streams can generate sufficient overpressure to directly cause failure of nearly flat slopes (Stoecklin et al., 2017), or weaken the slope to such an extent that a moderate earthquake can cause failure (Stigall and Dugan, 2010). Overpressure generated by the rapid loading of glacial deposits during short periods of peak glaciations on top of marine sediments is likely one of the main preconditioning factors for the Storegga Slide (Fig. 1) (Berg et al., 2005), and overpressure remnants are still observed behind its upper headwall (Strout and Tjelta, 2005). Oozes underlying Pleistocene glacial sediments have been suggested to affect lateral fluid migration (Bryn et al., 2005). In order to predict the amount of overpressure that can be generated by sediment deposition over time, i.e. during consolidation, information about sedimentation rates as well as the compressibility and permeability of the sediments and how these parameters change with increasing overburden stress and compaction is required (Urlaub et al., 2012; Kvalstad et al., 2005a).

So-called weak layers are often considered to host the slip facilitating translational failure at all scales (Locat et al., 2014). Examples are the Storegga Slide (Bryn et al., 2005; Solheim et al., 2005), the intermediate-sized Cap Blanc Slide (Urlaub et al., 2018) or the much smaller Finneidfjord Slide (Vanneste et al., 2012). In this study, we define a weak layer as any geological layer or a sequence of layers promoting slope instability. Trough mouth fans (TMFs) are depositional systems characteristic for high-latitude (formerly) glacial continental margins. TMFs are largely built up by (stacked) GDFs that were deposited in periods when ice streams reached the shelf edge (King et al., 1996; Laberg and Vorren, 1996; Elverhøi et al., 1997). There is ample evidence of the occurrence of submarine landslides in these TMFs (King et al., 1996; Vorren et al., 1998; Sejrup et al., 2005; Nygård et al., 2005; Hjelstuen et al., 2007; Rebesco et al., 2013), and TMFs are excellent records to study the relationship between large submarine landslides and ice-sheet changes on different types of margins (Vorren and Laberg, 1997; Pope et al., 2018). The seafloor typically dips less than $3^{\circ}$ in TMF areas (Gales et al., 2018). 
Furthermore, seismicity in TMFs was most likely higher shortly after the deglaciation due to glacioisostatic rebound (Byrkjeland et al., 2000; Owen et al., 2007; Lee, 2009). Following the suggestion of Hjelstuen et al. (2007), megaslides are here defined as mass transport deposits with volumes larger than $1000 \mathrm{~km}^{3}$.

In this study, we model the stability of the slope across the North Sea TMF (Fig. 1) during Pleistocene climate changes, focusing on the effect of rapid sediment deposition and seismic shaking. This type of modeling has previously not been published on TMF systems and has the potential to contribute to identify controlling factors of slope stability on the North Atlantic margin, where the volumes involved in submarine landslides are one or several orders of magnitude higher than their counterparts on active margins (e.g. Hühnerbach et al., 2004; Urgeles and Camerlenghi, 2013). The study presented herein addresses the following questions: (1) Can increased sedimentation rates at the North Sea TMF during a period with shelf edge glaciation generate sufficient overpressure on $\mathrm{a} \sim 1^{\circ}$ slope to cause slope failure?, (2) What is the effect of a glacimarine sediment layer at the base of rapidly deposited GDFs on slope stability?, (3) How important is the sedimentation pattern during the glacial period on slope stability?, and (4) What earthquake magnitude is required to trigger megaslides on a slope preconditioned by glacial sediment? Given some uncertainties in sediment parameters, as is often the case for submarine slope stability assessments (Vanneste et al., 2014), we emphasize that the results of our study should be interpreted in a qualitative rather than quantitative way.

\section{Geological setting}

The Pleistocene North Sea TMF lies at the outlet of the Norwegian Channel on the northern North Sea Margin (Fig. 1). Spreading over an area of $110,000 \mathrm{~km}^{2}$ and built up by nearly $40,000 \mathrm{~km}^{3}$ of sediments (Sejrup et al., 1996; King et al., 1996; Nygård et al., 2005; Hjelstuen et al., 2012), it is the largest Pleistocene TMF along the Norwegian continental margin (Fig. 1). The North Sea TMF is located in a region which has experienced subsidence rates of 0.7-0.8 $\mathrm{m} / \mathrm{kyr}$ during the mid- and late-Quaternary (Sejrup et al., 2004). The fan has mainly been fed by erosional products delivered to the upper continental slope by the fast-flowing Norwegian Channel Ice Stream during maximum Pleistocene 
glaciations in Marine Isotope Stages (MIS) 2, 6, 8, 10, and probably 12 (Fig. 3) (Sejrup et al., 2003; Nygård et al., 2005). The sediments deposited in the early Quaternary (2.6-0.8 Ma), however, are sourced from the Norwegian mainland in the east (Batchelor et al., 2017). The shelf geometry northeast of the North Sea TMF is uniform over a c. $150 \mathrm{~km}$ long distance, with a width of c. $60 \mathrm{~km}$.

The volcanic Møre Marginal High (Fig. 2) divides the wedge-shaped North Sea TMF into two main provinces, a proximal fan province characterized by an alteration between deposits of GDFs, glacimarine sedimentation and slide escarpments and deposits, and a distal fan province dominated by slide debrites (Nygård et al., 2005). The Pleistocene sedimentary column within the proximal province has been divided into ten sequences (P1-P10) (Fig. 2) (King et al., 1996; Nygård et al., 2005), reflecting the change in the sedimentary processes through glacial-interglacial cycles. Sequences P1, P4, P5, P8 and P10 are dominated by GDFs, identified as acoustically transparent stacked lobate lenses in the acoustic data (Sejrup et al., 1996; King et al., 1998; Nygård et al., 2002). The glacimarine sediments (P2 and P6) drape the GDFs and have an acoustically laminated seismic facies, which is only visible where the sediment package is thick enough. These glacimarine deposits are characterized as more fine-grained sediments with lower unit weights and shear strengths, and higher water contents, void ratios, permeabilities, consolidation coefficients, compressibilities, plasticity and sensitivity values compared to the GDFs (King et al., 1998; Berg et al., 2005; L'Heureux et al., 2013; Llopart et al., 2014).

The three slide debrites (P3, P7 and P9) identified in the North Sea TMF are characterized by an acoustically chaotic facies between a smooth lower and irregular upper surfaces. The Tampen Slide (Figs. 1, 2), one of numerous prominent megaslides along the Norwegian-Barents Sea continental margin (e.g. King et al., 1996; Solheim et al., 2005; Hjelstuen et al., 2007), is the most recent submarine landslide initiated at the North Sea TMF. It is suggested to be of late MIS 6 age ( 130 ka, Nygård et al., 2007). It has been suggested that MIS 6 was characterized by at least three shelf edge ice sheet oscillations (Fig. 3) (Nygård et al., 2005). The debrite of the Tampen Slide (P3 in Fig. 2) has been traced from c. $500 \mathrm{~m}$ water depth at the shelf break to more than $2000 \mathrm{~m}$ water depth some $200 \mathrm{~km}$ basin-ward, and its $\sim 300$ m-high headwall is located c. 10 km west of the shelf break (Fig. 2). Nygård et al. (2005) 
estimated a sediment volume of $1400 \mathrm{~km}^{3}$ failing along a $0.2-0.7^{\circ}$, and locally steeper $\left(1^{\circ}\right)$, slope for the Tampen Slide.

Additional to the $\sim 130 \mathrm{ka}$ old Tampen Slide, the North Sea TMF experienced megaslides during MIS 9 (Møre Slide) and MIS 11-12 (Stad Slide; Fig. 3) (Nygård et al., 2005; Solheim et al., 2005; Hjelstuen and Grinde, 2016). The TMF did not fail during the last glacial-interglacial cycle; however, the $\sim 8100$ cal. yrs BP Storegga Slide happened nearby (Figs. 1, 2) (Bryn et al., 2005; Haflidason et al., 2005; calibration curve from published articles). These megaslides affect different areas of the North Sea TMF (Hjelstuen et al., 2007), as the Pleistocene ice-stream patterns have changed and sediment sources varied (Batchelor et al., 2017).

In the study area, average sedimentation rates are in the order of c. $1 \mathrm{~m} / \mathrm{kyr}$ for the glacial and deglacial periods (Lekens et al., 2005; Nygård et al., 2007), whereas the rates during interglacials fall in the range of $0.05-0.10 \mathrm{~m} / \mathrm{ka}$, i.e. only a fraction of the rate documented for glacial periods (Haflidason et al., 1998). Locally higher sedimentation rates of up to $36 \mathrm{~m} / \mathrm{ka}$ are estimated near the Storegga Slide headwall during the last deglaciation (Hjelstuen et al., 2004). The excess load of rapidly-deposited glacial sediments and the disappearing ice sheets are suggested to have enhanced the local stress field and, in turn, the seismic activity in the region (Byrkjeland et al., 2000).

\section{Model configuration and slope stability analysis}

In this study, we use the Finite Element Modeling software ABAQUS (6.13-1) from Simulia to test various hypotheses to describe the potential for slope failure in the entire model domain at any time during deposition. We therefore perform a fully-coupled fluid flow-stress analysis using a model setup that accounts for large displacements using the finite strain theory.

\subsection{Model setup and input parameters}


The Finite Element 2D Model input is partly based on the continental slope setting in the area of the Tampen Slide headwall including seismic reflection data interpreted by Nygård et al. (2005) (Fig. 2). The model domain has been subdivided into four simplified discrete Model Units (MU) (Fig. 4; Tab. 1). The seismic sequences P6-P10 (Figs. 2, 4) are summarized as "fill" material and represent MU4. We consider that MU4 is in stress equilibrium, assuming that the MIS 9 Møre Slide released the overpressure that might had accumulated before failure. GDF deposits representing MIS 8 (P5, 300-243 ka), which show the best-developed mounded seismic facies on the North Sea TMF (Nygård et al., 2005), overlie the "fill"-fundament and represent MU3. We assume that the deposits representing the MIS 8 deglacial and the MIS 7 interglacial, which cannot be identified in the seismic data, have been eroded by the Tampen Slide. A $10 \mathrm{~m}$ thick layer of stratified fine-grained glacimarine sediments is therefore included for this time period, defining MU2 (Fig. 4; Tab. 1). We estimate this layer to have a thickness of $10 \mathrm{~m}$ based on deglacial and interglacial sedimentation rates in the study area (Haflidason et al., 1998; Becker et al., 2018). The thickness of the sediments removed by the Tampen Slide (MU1) is estimated based on the intact stratigraphy upwards of the Tampen Slide headwall and extrapolated to simulate pre-failure conditions. We further assume MU1 to be thickest $20 \mathrm{~km}$ downslope of the Tampen Slide headwall, corresponding with the right lateral boundary of the model. Characterized as relatively uniform in its rheological properties, MU1 consists of mainly GDFs deposited during MIS 6 (Tab. 1).

Whereas the Storegga Slide developed retrogressively (Gauer et al., 2005), such behavior is not evident from the present seismic data in the Tampen Slide region. As we assume that the Tampen Slide was not initiated by the destabilization of a locally steeper slope, modeling a laterally complete profile is not expected to add significantly to the modeling results. We therefore laterally limit the model domain to $40 \mathrm{~km}$, consisting of a $10 \mathrm{~km}$ wide continental shelf and $30 \mathrm{~km}$ of continental slope. The paleo-slope dip used in the model $\left(0.6^{\circ}\right)$ runs parallel to the basal reflector of the Tampen Slide (Fig. 4).

\section{Sediment properties}

The three materials used in the model are characterized by GDFs (MU3), mainly GDFs (MU1) and glacimarine sediments (MU2) (Fig. 4, Tab. 1). All deposits are modelled as non-linear porous 
elastoplastic materials, described by the Modified Cam Clay constitutive model. All soil units are inferred to have a Poisson ratio $(v)$ of 0.3 , and a friction angle $(\varphi)$ of $28^{\circ}$. These values are based on measurements performed on GDFs from a similar geological setting, i.e. the upper-middle continental slope of the Storfjorden TMF (Llopart et al., 2014). The dry density ( $\left.\rho_{\text {dry }}\right)$ is $1.8 \mathrm{~g} / \mathrm{cm}^{3}$ for glacimarine deposits and $2.0 \mathrm{~g} / \mathrm{cm}^{3}$ for the GDF-dominated modeling units (Tab. 2) (King et al., 1998).

For the consolidation properties (compressibility $(\lambda)$ and permeability $(\mathrm{k})$ ) we use values measured on samples of glacial debris and glacimarine deposits from the nearby Ormen Lange gas field area on the upper Møre continental slope (Kvalstad et al., 2005a) (Fig. 1, Tab. 2). Even if the composition of glacial sediments is documented to vary in time and space (King et al., 1996), the use of these values can be justified as we expect similar depositional environments and similar sediments to be represented in the neighboring North Sea TMF. The slope of the normal compression line in the Modified Cam Clay model $(\lambda)$, hereafter referred to as compressibility for simplicity, decreases with decreasing void ratio, averaging at 0.09 for GDFs and 0.29 for glacimarine deposits. The compressibility of mainly glacial debris (MU1) is 0.1 for all void ratios due to lack of consolidation tests for this sediment type. Permeability $(\mathrm{k})$ is a function of porosity $(\mathrm{n})$, and is defined as $\log 10(\mathrm{k})=11.5 \cdot \mathrm{n}-14.6$ for packages consisting of GDFs and mainly GDFs, and $\log 10(\mathrm{k})=7.6 \cdot \mathrm{n}-13.8$ for glacimarine deposits. The void ratio at $1 \mathrm{kPa}$ (e0, void ratio at seafloor) is set to 3.5 (equals a porosity of 0.78 ) for the glacimarine sediments and 1.2 (equals a porosity of 0.55 ) for the GDF-dominated modelling units (Tab. 2).

\section{Simulating sediment deposition during MIS 6}

We simulate sediment deposition during MIS 6, at the end of which the Tampen Slide occurred, by consecutively "switching on" eight elements rows. Displacement and pore-pressure plane-strain elements are activated and stacked on top of the elements of the model in a sequence of steps. The load is gradually increasing over time within the deposited elements. Pore pressure development and slope stability are analyzed in both the newly deposited as well as the pre-existing sediments during the deposition of the element rows which define MU1. 
Back-stripping of the stratigraphy allowed to better estimate the real sediment thicknesses at the time of deposition. Using a calculated decompacted MU1 thickness of $\sim 340 \mathrm{~m}$ at the location of the Tampen Slide headwall, each row is $\sim 40 \mathrm{~m}$ thick. An average compaction of $30 \%$ caused by rapid glacial sediment loading is comparable to previous studies, in which compaction was estimated to up to $40 \%$ (Hjelstuen et al., 2005).

\section{Meshing, boundary and initial conditions}

The mesh used in the modelling consists of 27,000 8-node biquadratic displacement, bilinear pore pressure elements with reduced integration (Fig. 4). The elements have a size of 40x40 m in MU1 and 10x40 m in MU2, while a coarser mesh size was vertically adapted down in the model domain. These differences in element size are reasonable, as the uppermost sediment package is the area of interest and as changes in mechanical properties are less pronounced at larger depths (Hamilton, 1976; Karig and Hou, 1992). The element size also increases towards the lateral boundaries. The model does not allow any displacement at its base, while its lateral boundaries are constrained in the $\mathrm{x}$-direction and free at its top. The lateral-landward and bottom boundaries are impermeable (Fig. 4), whereas fluids are free to flow from the surface, where overpressure is zero. The different model units extend over the entire length of the model domain and are permeable at their upper and lower boundaries (Fig. 4).

For the initial conditions of the model, we assume that the sediments are normally consolidated, with a void ratio defined according to stress conditions and overpressure defined to be zero. This can be justified as (i) a major landslide (Møre Slide; Fig. 2) is assumed to release overpressure and reset the stress regime to overconsolidated conditions with zero excess pore pressure, and (ii) a long interglacial time period (243-191 ka; MIS 7) preceded the time of initiation of our model (Fig. 4), during which large amounts of fluids are expected to have escaped and overpressures to have dissipated as sediments have been deposited at low rates.

\subsection{Model runs}

Based on the age constrains of sequence P4 and the Tampen Slide (Nygård et al., 2005), we suggest that MU1 represents MIS 6 and that the Tampen Slide was initiated at the end of this MIS ( 130 ka). We 
initiate our model at the beginning of MIS 6, and then run it in eight steps and a total of $61 \mathrm{kyr}$, representing the sedimentation history during MIS 6 . The added soils are consolidating in the process. Gravitational loads for the individual elements are ramped up during the step, with no load in the beginning and complete load at the end of a step.

Uncertainties in timing and sediment decompaction have a large effect on the sedimentation rates. While the thickness of sequence P4 can be estimated with confidence, there are no age dates available from this $340 \mathrm{~m}$ thick sequence. In order to address this uncertainty, we ran models with three different sedimentation scenarios to identify situations in which particularly high pore pressures may be generated.

The first scenario, considered the reference model, uses constant sedimentation rates of $3.3 \mathrm{~m} / \mathrm{kyr}$ for MIS 6 and geotechnical values measured on samples from nearby locations (Kvalstad et al., 2005a). The goal of the reference model was to evaluate if constant temporal sediment loading has a destabilizing effect. Previous modelling studies have identified compressibility as a key factor for overpressure generation due to sediment deposition (Urlaub et al., 2012; Urlaub et al., 2015). We therefore use a higher compressibility value for the uppermost layer (MU1) than provided by Kvalstad et al. (2005a) in one scenario.

Ice-sheet configurations and sedimentation rates might change during a marine isotope stage (Becker et al., 2018). In the second scenario, the sedimentation rates follow a pattern similar to the last glacial (MIS 2), with an increase in sediment accumulation in the second half of the glacial (Hjelstuen et al., 2004). Such an ice sheet configuration has also been suggested for MIS 8 (Fig. 3) (Nygård et al., 2005). In this scenario, three element rows (equivalent to c. $120 \mathrm{~m}$ decompacted sediment) are deposited in the first $30 \mathrm{ka}$, and five element rows (equivalent to c. $200 \mathrm{~m}$ decompacted sediment) in the last $30 \mathrm{ka}$. This scenario should test if episodically high sedimentation rates may generate a significant amount of overpressure.

Sequence P4 can be separated into three GDF sequences, each having a maximum thickness of 100-200 m (Nygård et al., 2005). These seismostratigraphic observations could indicate rapid on-off switching 
of the Norwegian Channel Ice Stream, suggested for other glacials (Nygård et al., 2007; Becker et al., 2018). Thus, in the third scenario, the GDF sequences of MU1 are each defined by two rows of high sedimentation rates. These rows were separated from each other by one row with half the sedimentation rate, and each GDF sequence was then deposited over $12 \mathrm{kyr}$. This model scenario evaluates the effect of pulses of high sedimentation rates on slope stability.

\subsection{Slope stability analysis and earthquake calculation}

The overpressure ratio $\left(\lambda^{*}\right)$, defined as the excess pore pressure $\left(p_{e}\right)$ divided by the vertical effective stress $\left(\sigma^{\prime}{ }_{v}\right)$ and the excess pore pressure, is a useful measure for the degree of overpressurization of the slope. For example, for a slope gradient of $\sim 1^{\circ}$ consisting of homogenous sediment with a friction angle of $30^{\circ}$, an overpressure ratio of 0.96 is required to induce slope failure without any external force (Urlaub et al., 2015).

$\lambda^{*}=\left(\frac{p-p_{h}}{\sigma_{v}-p_{h}}\right)=\frac{p_{e}}{\sigma^{\prime}{ }_{v}+p_{e}}$

For the case that overpressure generated by rapid sedimentation is insufficient to initiate slope failure, we couple the 2D Finite Element Modeling with cyclic loading. Earthquakes can contribute to the destabilization of a slope, as the horizontal component of the earthquake acceleration generates shear stresses (Hampton et al., 1996). According to finite slope stability models and following the approach of ten Brink et al. (2009), earthquake-triggered submarine landslides in soft sediments occur when the shear stress on the slip surface exceeds the undrained shear strength of the sediment (e.g. Morgenstern, 1967). This condition is expressed by the Factor of Safety (FoS) as

$F o S=\frac{\sigma_{v}^{\prime} \cdot \tan \Phi_{c r i t}}{\tau+F_{e q}}$

where $\sigma^{\prime}$ is the vertical effective stress, $\Phi_{\text {crit }}$ the critical friction angle, $\tau$ the shear stress and $F_{\text {eq }}$ the earthquake acceleration shear stress parallel to the slope. In order to initiate slope failure (FoS $\leq 1)$, we calculate

$$
F_{e q}=\left(\sigma_{v}^{\prime} \cdot \tan \Phi_{c r i t}\right)-\tau
$$

In previous studies (ten Brink et al., 2009; Stigall and Dugan, 2010), the critical horizontal earthquake acceleration $\mathrm{k}_{\mathrm{y}}$ has been calculated to 
$k_{y}=\frac{F_{e q}}{\sigma_{v}^{\prime}+p_{e}}=\frac{\left(\sigma_{v}^{\prime} \cdot \tan \Phi_{c r i t}\right)-\tau}{\sigma_{v}^{\prime}+p_{e}}$

309

310

where $p_{e}$ is the excess pore pressure.

We follow ten Brink et al. (2009) and link the critical acceleration, $\mathrm{k}_{\mathrm{y}}$, to the spectral acceleration required for triggering slope failure, $\mathrm{k}_{\mathrm{PSA}(\mathrm{T}=0.75) \text {, as }}$

$k_{P S A(T=0.75)}=\frac{k_{y}}{0.15 \cdot 3.5}$

This relation is applied by ten Brink et al. (2009) for the slopes offshore Eastern North America which are geologically and tectonically similar to our study area, and assume the relation to be a reasonable choice for our application. We then relate the obtained $\mathrm{k}_{\mathrm{PSA}(\mathrm{T}=0.75)}$-value to earthquake magnitude and distance by considering an empirical ground motion prediction equation (GMPE). As no GMPE has been developed according to modern standards based on Norwegian data, we adopt the recent relation by Pezeshk et al. (2015) which is valid for Eastern North America, where ground motion characteristics are similar to our study area.

\section{Results}

We assess the effect of different scenarios of temporal sediment loading, compressibility contrasts, and a glacimarine sediment layer on pore pressure generation and slope stability. The results are presented as vertical profiles located $10 \mathrm{~km}$ downslope from the shelf break $(x=20 \mathrm{~km}$, Fig. 4). This location represents the Tampen Slide headwall (Fig. 2), and likely the onset of failure assuming that the landslide did not develop retrogressively.

\subsection{Reference model}

Fig. 5 presents the results of the reference model, characterized by constant sedimentation rates and measured hydro-geomechanical sediment properties (Tab. 3), after the 61 ka long time span of MIS 6. The results show that excess pore pressure $\left(\mathrm{p}_{\mathrm{e}}\right)$ increases continuously with depth and time (Figs. 5a, 7a-1) to $800 \mathrm{kPa}$ at $\sim 500 \mathrm{~m}$ below seafloor (bsf). Below this level, the excess pore pressure increases to $3000 \mathrm{kPa}$ towards the bottom of the model (Fig. 5a). The vertical effective stress $\left(\sigma^{\prime}{ }_{\mathrm{v}}\right)$ is increasing constantly from $0 \mathrm{kPa}$ at the seafloor to $30000 \mathrm{kPa}$ at the base of the model (Fig. 5b). 
The constant sedimentation rates of $3.3 \mathrm{~m} / \mathrm{kyr}$ during MIS 6 result in maximum overpressure ratios $\left(\lambda^{*}\right)$ of 0.16 at depths of $\sim 200 \mathrm{~m}$ bsf, with $\lambda^{*}$-values varying from 0.1 to 0.16 within the rapidly-deposited MU1 (Figs. 5c, 7a-2). While $\lambda^{*}$ rapidly increases during the deposition of the first two rows, its rate of increase is lower during the deposition of the last six rows (Fig. 7a-2). The fluid gradients indicate an eastwards-oriented fluid flow, which is dominated by a vertical component (Fig. 5d). Although sediment depths with maximum overpressure ratios are likely to be affected by the Tampen Slide, less than $16 \%$ of the total overburden stress taken up by the excess pore pressure is insufficient to cause slope failure. Thus, constant sedimentation rates in the North Sea TMF during MIS 6 most likely did not generate sufficient excess pore pressure to cause slope failure.

\subsubsection{Changes in compressibility}

Deterministic sensitivity analyses on models used in previous studies (Urlaub et al., 2015) showed a high sensitivity of overpressure generation to compressibility. Therefore, we also ran the reference model under the assumption that the material characterizing MU1 is more compressible than expected. Therefore, the compressibility of MU1 was increased from 0.1 in the reference model to 0.13 for the compressibility test (Tab. 2, Fig. 6). The results from this model run show that the excess pore pressure rises with a steep gradient from the seafloor to values of $2500 \mathrm{kPa}$ at the base of the highly-compressible layers (Fig. 7b-1), and that the $\mathrm{p}_{\mathrm{e}}$-values are more than doubled compared to the $\mathrm{p}_{\mathrm{e}}$-values in the reference model when using an increased compressibility (Fig. 7a-1). Excess pore pressures increase with a much lower gradient for low-compressible sediment properties in MU1 (Fig. 7a-1). Within the underlying MU3, the excess pore pressures rise with the same gradients for both model runs.

This model run results in overpressure ratios of 0.55 at the top of the glacimarine layer at the profile location (MU2, Figs. 6, 7b-2). The highest overpressure ratios of 0.7 occur at the right-hand-size boundary of the model (Fig. 6b), where the deposited sediment package is thickest. Overpressure ratios decrease both atop and below MU2. Both a normal- and a high-compressible MU1 result in overpressure generation with time, with most of the overpressure generated during the first 15 ka (Figs. 7a-2, 7b-2). However, we note that utilizing a higher compressibility results in more significant overpressure ratio increases between the different time steps (Figs. 7a-2, 7b-2). Thus, the model run shows that an increase 
in compressibility from 0.1 to 0.13 has large effects on overpressure generation. An increase of $33 \%$ in compressibility results in an increase of $200 \%$ of overpressure. On the other hand, void ratio values, decreasing through time, are comparable for both the reference and the enhanced compressibility model runs (Figs. 7a-3, 7b-3).

\subsubsection{Glacimarine layer}

The modelling shows that the highest overpressure ratios occur within the glacimarine layer (Figs. 5-7). Therefore, this unit could represent the level in the model domain which is closest to fail or to act as a slip plane. The overpressure ratio increases with depth, and reaches its maximum values at the top of the glacimarine layer or slightly above (Figs. 7a-2, 7b-2). The glacimarine layer is furthermore characterized by a higher void ratio, which slightly decreases with time (Figs. 7a-3, 7b-3). While excess pore pressures are more or less constant within the glacimarine layer (Fig. 7a-1, 7b-1), the overpressure ratios decrease in this unit (Fig. 7a-2, 7b-2), which probably can be explained by an increase in vertical effective stresses. Similar $\mathrm{p}_{\mathrm{e}}$-gradients are observed for MU1 in the reference model compared to the model scenario from which the glacimarine layer was excluded (Figs. 7a-1, 7c-1). The glacimarine layer results in increased overpressure ratios in MU1 for the compressibility test run (Fig. 7b-1). Removing the glacimarine layer results in lower excess pore pressures and overpressure ratios, and no contrast in the void ratio values (Fig. 7c). The inherited effect of the glacimarine draping sediment layer at the base of the rapidly deposited GDFs is thus an increase in the gradients of both excess pore pressures and overpressure ratios in MU1 as well as a contrast in permeability.

\subsection{Variability in sedimentation rates}

The first five rows of the model, comprising $200 \mathrm{~m}$ of sediments, were activated after different periods to test the effect of different temporal or staged loading on slope stability. In the reference model (Fig. 8a), these rows were constantly deposited with a rate of $3.3 \mathrm{~m} / \mathrm{kyr}$. During this model run, the excess pore pressure and overpressure ratio at the top of the glacimarine layer steadily increase to values of $\sim 450 \mathrm{kPa}$ and 0.13 , respectively. While $\mathrm{p}_{\mathrm{e}}$ is showing a constant increase in time, $\lambda^{*}$ has a stronger rise during the deposition of rows 1 and 3 (Fig. 8a). We also note that the overpressure ratio is highest within the glacimarine layer itself, but that the differences to the neighboring sediments are small. 
The model run of an ice-sheet build-up scenario (Fig. 8b), with sedimentation rates of $2.4 \mathrm{~m} / \mathrm{kyr}$ for the first three rows and increased sedimentation rates of $4.2 \mathrm{~m} / \mathrm{kyr}$ for the last two rows, results in higher $\mathrm{p}_{\mathrm{e}^{-}}$and $\lambda^{*}$-values at the top of the glacimarine layer compared to the reference model. The excess pore pressure and overpressure ratio increase significantly during the deposition of the first rapidly-loaded row (row 4), and reach a maximum of 0.2 at the depth of the glacimarine layer. The excess pore pressure in MU1 is similar to the excess pore pressure generated in the reference model. The vertical and lateral profiles show that the highest overpressure values of this scenario are not generated within the glacimarine layer, but rather at the interface of the glacimarine layer and the rapidly-deposited GDFs (Fig. 8b).

In the switch on/off scenario (Fig. 8c), excess pore pressures increase during the deposition of the four rapidly-deposited rows (4.2 m/kyr, rows 1-2 and 4-5), whereas no change is observed when deposition is slow (2.1 m/kyr, row 3). Overpressure ratios of 0.2 are generated at the top of the glacimarine layer at the end of both pulses of rapid sedimentation. Episodically high sedimentation rates may generate increases of $+300 \mathrm{kPa}$ per row in excess pore pressure and +0.07 per row in overpressure ratio. However, episodically high overpressure dissipation starts once the episode of high load is terminated. During the anticipated switch-off phase of the ice stream, the overpressure ratio is significantly decreasing to values of $\sim 0.1$ in the glacimarine layer. Unlike the other two scenarios, the switch on/off scenario shows highest overpressure ratios within MU1 and not in the glacimarine layer where overpressure decreases. At the end of the model run ( 5 rows or $200 \mathrm{~m}$ of sediment), the overpressure ratio is $\sim 0.05$ higher compared to the reference model for depths affected by the Tampen Slide.

In summary, these models show that the excess pore pressure increases either continuously or more abruptly in time depending on the sedimentation pattern. However, the overpressure ratio in the glacimarine layer and MU1 generated after the deposition of the five rows do not significantly vary for the different sedimentation patterns. We also observe that episodically high sedimentation rates cannot compensate for the dissipating pore pressure during periods of low sedimentation. Maximum overpressure ratios develop either at the interface between the glacimarine layer and MU1, or within MU1. Rapid sedimentation rates result in maximum overpressured slopes at depths expected to be the 
base of the Tampen Slide or above, whereas lower overpressures are generated for constant sedimentation rates. The model shows that the maximum overpressure ratio at the end of row 5 is 0.2 , and that the totally generated overpressure is low.

\subsection{Slope stability and the effect of seismic shaking}

The results obtained from the various models, and particularly the overpressure ratio $\left(\lambda^{*}\right)$ and the Factor of Safety (FoS), were used to analyze slope stability. The FoS, defined by the failure-resisting strength of the sediment divided by failure-inducing stresses (Formula 2), was $>1$ at any time of deposition, and the slope is therefore considered stable. As sedimentation-related pore pressure generation cannot explain the Tampen Slide, we consider the possibility of having an earthquake as an external trigger mechanism. Highest overpressure ratios (Fig. 7a-2, 7b-2), and shear stress values of up to $\sim 110 \mathrm{kPa}$ are observed within the glacimarine layer of the reference model (Figs. 9a, b), indicating that the slope is closest to failure at this depth not only for the selected profile, but for the entire model. The required additional horizontal loading by earthquakes $\left(\mathrm{F}_{\mathrm{eq}}\right)$ to cause instability is in the order of 1.9 MPa. The critical horizontal earthquake acceleration $\left(\mathrm{k}_{\mathrm{y}}\right)$ at the location of the Tampen Slide headwall at the depth of the glacimarine layer is calculated to $0.49 \mathrm{~g}$, which corresponds to $\mathrm{k}_{\mathrm{PSA}(\mathrm{T}=0.75)}=0.93 \mathrm{~g}$ (Fig. 9c). By applying the empirical ground motion prediction equation of Pezeshk et al. (2015), this level of ground shaking can be generated by an earthquake of magnitude M6.9 or larger in the immediate vicinity of the slide headwall, or by an event with M7.5 or larger at a distance of up to $3.5 \mathrm{~km}$ from the Tampen Slide headwall.

\section{Discussion}

Here, we evaluate the effect of different glacial sedimentation patterns and the $10 \mathrm{~m}$-thick glacimarine sediment layer on overpressure generation and slope stability of the North Sea TMF. Potential trigger mechanisms for the Tampen Slide and future slide activity in the $\sim 1^{\circ}$-dipping North Sea TMF are discussed based on seismic and overpressure quantification. Finally, we discuss the results from this study in a global perspective.

\subsection{Effect of glacial sedimentation patterns on slope stability}


442 The modelling shows that excess pore pressures build up due to the deposition of GDFs during MIS 6.

443 The highest excess pore pressures and overpressure ratios are related to increased sediment 444 accumulation in the second half of the model run or during extreme episodic pulses, whereas constant 445 sedimentation rates result in a more stable slope, i.e. with less excess pore pressure generation. However, 446 the magnitude of the resulting overpressure ratios at the end of the glacial stage does not vary significantly between the different models. We explain the lower overpressure ratios generated after 448 time periods with decreased sedimentation rates (Figs. 8b, 8c) by pore pressure dissipation when 449 sedimentation rates were low to medium. The sedimentation rates used for the model are based on stratigraphical constraints (Fig. 2). However, other studies indicate higher sedimentation rates along the

451

452

Norwegian shelf break (Dimakis et al., 2000; Hjelstuen et al., 2004; Nygård et al., 2007). Previous studies also suggest that shelf-edge glaciations only lasted for short periods (Nygård et al., 2007; Becker et al., 2018). Thus, loading the North Sea TMF over a very short time period with extremely high sediment volumes could generate sufficient overpressure for slope failure. However, in order to fulfill the age constrains of MU1 (61 ka), such periods characterized by extreme loading would have to be compensated by periods characterized by low sedimentation rates, which is rather unlikely during shelf edge glaciations. The model runs indicate that an ice stream needs to be located near the shelf edge for high sedimentation rates to be maintained for most of a glaciation in order to create a slope more vulnerable to fail. Studies from the Gulf of Mexico show that sedimentation rates of 6-9 m/ka resulted in overpressure ratios of 0.7-0.8 (Schneider et al., 2009), indicating that even a doubling of the sedimentation rates at the North Sea TMF would probably not lead to overpressure-driven slope failure.

Our models suggest that compressibility has a large effect on overpressure generation (Figs. 6, 7b). Strongly increased overpressure ratios (Fig. 7b-2) indicate that sediments characterized by a higher compressibility could have contributed to slope instability along the gently-dipping seabed of the North Sea TMF. However, compressibility values $>0.13$ for MU1 would be required to generate sufficient overpressure, which may be within the measuring error. This test showed that small changes in compressibility have a high impact on overpressure generation. 
Numerical slope stability analysis of the Santa Barbara basin of the California borderland suggests that

469

470

471

472

473

474

475

476

477

478

479

480

481

482

pre-conditioning through rapid sedimentation has controlled the emergence of large, slope-parallel landslides on the northern flank of that basin (Stoecklin et al., 2017). However, high sedimentation rates at the North Sea TMF during glacial stages cannot generate sufficient overpressure to cause slope failure on the $\sim 1^{\circ}$-dipping seabed. Different temporal sedimentation patterns do not significantly affect the amount of overpressure generated at the end of the model runs. The model scenarios assume overpressure to be zero at the beginning of the simulations, which is a rather conservative estimation. The role of ice load on the continental shelf and fluid migration from Miocene ooze layers have not been included as contributing factors to overpressure generation. Glacial unloading related to a melting Norwegian Channel Ice Stream most likely resulted in fluid migration away from the slope and towards the shelf, making the slope more stable. However, as the Norwegian Channel Ice Stream must have been warm-based, and ice overload did not significantly exceed the water column, ice unloading is probably only having a minor effect. Loading and unloading of the slope by ice sheet advances and retreats has been shown to have only minor effects on continental slope stability (Kratzke, 2018), and can thus be neglected.

\subsection{Potential of glacimarine deposits acting as a weak layers}

Bedding-parallel layers may represent so-called weak layers which play a key role in the development of slope failures (Haflidason et al., 2003; Berg et al., 2005; L'Heureux et al., 2013; Locat et al., 2014). However, slopes have been modelled to be prone to fail along preferential horizons at defined depths without the presence of an intrinsic weak layer (Stoecklin et al., 2017). For the North Sea TMF, observations in the seismic profiles show that sediments mainly consisting of GDFs (MIS 6) have been removed above a package consisting of GDFs (MIS 8) during the Tampen Slide (Fig. 2). We note that no glacimarine sediment package has been resolved in the seismic profile of the study area, but deglaciation packages have been observed for the time periods related to MIS 2 and MIS 6 on the Vøring Plateau (Fig. 1) (Haflidason et al., 2003; Lekens et al., 2005). Therefore, we suggest that such a deglacial and/or interglacial package has also existed in the area affected by the Tampen Slide, but has either been eroded by the megaslide or is too thin to be resolved in the seismic profiles (vertical resolution of c. 10 
m, Nygård et al., 2005). The surface parallel to the seafloor, at a depth correlating with the glacimarine sediment deposits, is characterized by highest void ratios, highest overpressure ratios and highest shear stresses (Figs. 7, 9).

The high permeability of the glacimarine layer could have accommodated vertically-oriented fluid flow (Fig. 10a). At the same time the low-permeable overlying package, mainly consisting of GDFs, acted as a barrier for vertical fluid flow. Combining these two effects would explain the highest overpressures at the very top of the glacimarine layer (Fig. 7). Thus, permeability contrasts linked to the glacimarine layer would significantly contribute to the preconditioning of the Tampen Slide. Gas accumulation below GDFs has also been suggested by ocean bottom seismometer investigations in the Storegga Slide area (Mienert et al., 2005b), and support our hypothesis that GDFs are a trap to vertical fluid flow. We suggest fluids to accumulate at the top of the glacimarine layer.

Therefore, we conclude that the glacimarine layer itself or the interface of the glacimarine layer with the overlying GDF-dominated sequence most likely acted as a weak layer for the Tampen Slide (Fig. 10a). Similar failure planes are found in fine-grained depositional units, such as plumite or glacimarine and hemipelagic sediments (Haflidason et al., 2003; Berg et al., 2005), on the mid-Norwegian continental margin, or in laminated glacimarine clays at the upper continental slope off Vesterålen (L'Heureux et al., 2013). Reported excess pore pressures of up to 0.2 within contouritic sediments below GDFs in the Storegga Slide area (Bryn et al., 2003), which also correlate with zones of anomalously low s-wave velocities (Mienert et al., 2005b), support the result of our model simulations. Although the stability at the expected Tampen Slide failure depth is reduced, overpressure-driven slope failure is not suggested.

The effect of sedimentological and geotechnical properties of glacimarine layers beneath rapidly deposited glacial debris has previously been discussed at different locations within the North Atlantic. These layers are reported to have higher water contents and lower shear strengths (Lucchi et al., 2012), and are suggested to develop local overpressure zones (Bryn et al., 2003; Mienert et al., 2005b; Berg et al., 2005; Llopart et al., 2014). Coarser-grained glacial deposits overlain by less-permeable glacial sediments in the Barents Sea have been suggested to be charged by fluids and to act as weak beds (Bellwald and Planke, 2018). 


\subsection{Quantification of trigger mechanisms of the Tampen Slide}

523 It seems that high sedimentation rates alone did not lead to failure of the Tampen Slide, even if using 524 increased compressibility values for the deposited GDFs in MIS 6. Gas hydrates, indicated by the

525

526

527

528

529

530

531

532

533

534

535

536

537

538 presence of a bottom simulating reflector, are suggested to have contributed to the triggering of the Storegga Slide (Bünz et al., 2003; Mienert et al., 2005a). However, gas hydrates are rather unlikely to be built within GDFs (Bünz et al., 2003; Mienert et al., 2005a), and no gas hydrate indicators have been observed in conventional seismic profiles of the North Sea TMF. Therefore, gas hydrates are rather unlikely to have acted as an additional fluid source affecting overpressure build-up for the Tampen Slide. However, even if not identified in the seismic profiles, the presence of gas hydrates at the North Sea TMF at the age of the Tampen Slide cannot be excluded.

The Tampen Slide could have been initiated at a locally steeper slope at the lower continental slope (Fig. 2), similarly to which has been proposed for the Storegga Slide (Gauer et al., 2005; Kvalstad et al., 2005b), and then developed retrogressively. However, as the lower slope of the North Sea TMF is beyond the main depocenters of GDFs (Fig. 2), initiation in the steepest region could be problematic for the build-up of sufficient pore pressure. The Miocene ooze layer, suggested to favor increased fluid flow in the lower slopes of the Storegga Slide (Riis et al., 2005), is overlain by a significantly thicker Pleistocene sediment sequence in the North Sea TMF, and has thus not been included in the simulations. As the morphology of the Tampen Slide does not indicate retrogressive slide development (Nygård et al., 2005) and as overpressure does not appear sufficient for slope failure at the position of its headwall, we suggest that an external trigger is the most likely cause for the initiation of the Tampen Slide.

Our model results show that an earthquake of M6.9 or larger at a short distance from the Tampen Slide headwall could have triggered the Tampen Slide (Fig. 10b). At present, there is still a higher seismicity around the Quaternary depocenters than elsewhere along the Norwegian continental margin (Byrkjeland et al., 2000). An earthquake of magnitude M5.4 occurred in the distal part of the North Sea TMF as late as in 1988 (Norwegian National Seismic Network; www.skjelv.no), in an area where no active postglacial faults have been mapped. Faults with the potential for accommodating earthquakes of such magnitudes have not been identified in the North Sea TMF. However, seismic events in response to 
glacio-isostatic rebound offshore Norway, accommodating earthquakes of M6.5-7 without breaking the surface, are considered to be likely (Bungum et al., 2005). Studies within the Storegga Slide region demonstrated the potential for large postglacial earthquakes to occur and to be able to shake sediment layers to a length and degree, which may lead to slope failure for sediments with a deposition-related low FoS (Solheim et al., 2005; Bungum et al., 2005; Lindholm et al., 2005). Severe seismic loading has also been proposed for slope failures within glacimarine sediments off Vesterålen (L'Heureux et al., 2013). Studies from SE Canadian continental slopes suggest that the build-up of overpressure, linked to deposition of GDFs (Aksu and Hiscott, 1992; Hiscott and Aksu, 1994), allows earthquake-triggered failures along slopes with gradients as low as $1^{\circ}$ (Tripsanas et al., 2008; Piper, 2014). An earthquake has also been suggested to be the final trigger for submarine mass movements of slopes controlled by high sedimentation rates in the Santa Barbara Basin (Stoecklin et al., 2017). Thus, we suggest an earthquake at the end of MIS 6, coupled with moderate overpressure from rapid sedimentation, to have acted as the additional driving stress necessary for slope failure for the Tampen Slide (Fig. 10b). This earthquake could either have been triggered by stress changes related to sediment deposited on the North Sea TMF itself or by crustal readjustment after the ice sheet retreat, similar to what has been suggested for large slope failures on the continental slope off SE Canada (Piper et al., 2003). Slope stability is reported to increase with increasing frequencies of earthquakes and decreasing sedimentation rates (ten Brink et al., 2016). Thus, an individual high-magnitude earthquake in this seismically moderate region, characterized by high sedimentation rates during glacial stages, seems to be a possible final trigger mechanism. A high peak spectral acceleration with a short duration will not induce slope failure. However, this point has already been accounted for in the approach we follow (ten Brink et al., 2009).

The modelling attempt of this study included only one dimension of earthquake shaking, whereas seismic waves in reality affect the sedimentary sequence in three dimensions (Carlton and Kaynia, 2016). The lower earthquake frequencies are closer to the resonance frequency of sediment layers and attenuate more slowly within the sediments. Consequently lower earthquake frequencies have longer durations and a higher potential for fluid mobilization than the higher frequencies. Thus, we suggest that lower earthquake frequencies are more important for slope failure initiation (Kramer, 1996). 
Increased submarine landslide activity at glacial-interglacial transitions has previously been documented

577 (Maslin et al., 2004; Owen et al., 2007; Urgeles and Camerlenghi, 2013). We suggest that the earthquake

578 that may have initiated the Tampen Slide took place at the transition into MIS 5, when overpressure

579 ratios and seismic activity are assumed to be highest. This timing probably indicates a large difference 580 between slide initiation at the North Sea TMF and the Storegga Slide, which occurred $\sim 15$ kyr after peak glaciation (Haflidason et al., 2005). However, due to sparse chronostratigraphical constrains, we cannot exclude that the Tampen Slide was triggered during the MIS 5 interglacial or later. In that case the Tampen Slide had a similar delay as the Storegga Slide.

\subsection{Limitations of the numerical modeling study}

The numerical models incorporate uncertainties resulting from the limited resolution of seismic data for reconstruction of the sediment architecture, stratigraphy, as well as a lack of in-situ physical, mechanical, and seismological properties of the prevalent sedimentary units explained below in detail. There are actually no deep-drilling results available from the area, and geotechnical parameters are scarce. Furthermore, high-resolution 3D seismic data were not available either. Thus, the overall results of the numerical modeling conducted in this study should be understood qualitatively and the provided estimates of pore pressure levels and earthquake magnitudes considered as approximations of these values. Nevertheless, the parameters used are based on extensive geohazard assessment investigations for the nearby Ormen Lange gas field development (Kvalstad et al., 2005; and other) in a comparable geological setting. Aiming to test how slope stability changes with increasing overburden stresses, we used a reasonable range of parameters for the numerical simulations.

1) Physical and hydro-geomechanical sediment properties: As no hydro-geomechanical information is available from the North Sea TMF, we used hydro-geomechanical sediment properties measured on samples from the nearby Ormen Lange gas field area (Kvalstad et al., 2005; and others). Even though the composition of glacial sediments are known to vary in time and space (King et al., 1996), the similarity in environmental conditions allow for such a transfer. Due to limits in seismic resolution (max. frequency of c. 10 m; Nygård et al., 2005) and an absence of wells, we summarize the composition of model unit MU1 to be mainly GDFs. 

Tampen Slide occurred at the end of this marine isotope stage (Nygård et al., 2005). However, the

605

606

607 chronology of the North Sea TMF and the suggested date of the Tampen Slide, on which we base the sedimentation rates and overpressure build-up, are not well constrained or understood. Improvements in the chronological framework of the North Sea TMF are thus crucial to improve the modeling of sedimentation-related overpressure and triggering of megaslides.

3) Pre-slide stress conditions: Our model further assumed overpressure to be zero at the beginning of the simulations. However, there might be some overpressure at the model initiation, as suggested by lateral fluid migration sourced from Miocene oozes in the explanation of the early Holocene Storegga Slide (Bryn et al., 2005; Riis et al., 2005). However, the pre-slide conditions are impossible to reconstruct with the currently available data.

4) Seismological properties: The model was coupled to seismic shaking, which is based on formulas valid for eastern North America (ten Brink et al., 2009). The input parameters for these formulas are not calibrated against Scandinavia, and might be different for our study area. However, we assume a similar response due to similarities in geological and tectonical settings (Pezeshk et al., 2015). Thus, the earthquake triggering the overpressured slopes of the Tampen Slide could have been of lower magnitude than what we modeled in our study.

\subsection{Implications and global relevance}

Potential links between climate-controlled sedimentation, slope preconditioning, seismic activity and megasliding are demonstrated by numerical modeling of the Tampen Slide. However, the slopes of the North Sea TMF seem not to have failed in glacial stages with similar sedimentological and seismological conditions to the ones found at the end of MIS 6 (Fig. 3) (Nygård et al., 2005). It is not yet understood why megaslides at the North Sea TMF occurred in some periods characterized by rapid sedimentation, whereas the fan seems not affected by large slope failure in other periods. Megaslides during the last glacial/deglacial cycle have also not been observed along the Barents Sea margin (Hjelstuen et al., 2007). Lateral overpressure migration into the Storegga Slide area (Bryn et al., 2005) or the absence of a deglacial/interglacial sediment package at the base of the GDFs could additionally favor slope stability 
in this period. The observation that the North Sea TMF did not fail during some shelf edge glaciations generating GDFs supports an earthquake as the ultimate trigger mechanism for the Tampen Slide.

This study shows that changing glacial sedimentation patterns are not significant for the build-up of overpressure towards the end of glacial stages, but that the generation of overpressure is more depending on the total sediment overload. Our model runs indicate that overpressure ratios increase at a very low rate during periods characterized by glacial sedimentation, which are supposed to be some magnitudes higher compared to interglacial sedimentation rates (e.g. Lekens et al., 2005; Becker et al., 2018). Low seismicity, low interglacial sedimentation rates, and ongoing overpressure dissipation (Byrkjeland et al., 2000, Haflidason et al., 1998) result in a margin that at present is more stable than shortly after the last glacial retreat. Dissipating overpressures, related to decreased sedimentation rates and fluids being discharged into the modern system, have been reported by Strout and Tjelta (2005) from the Storegga Slide area and by Dugan and Flemings (2002) for the New Jersey margin. However, dissipating overpressures in the region of the North Sea TMF indicate that overpressures might still be present in the shallow sub-surface of the study area (Fig. 10b).

The effect of a glacimarine layer at the base of a package dominated by GDFs is modeled in this study, and could be applied to different TMF systems and glacially-affected margins all over the globe. The deposition of such thin layers seems to be fundamental for the evaluation of major slope failure in different glacial-interglacial cycles. However, there are still numerous uncertainties about weak layers. Probably required for megaslides, our knowledge about the thickness and geotechnical properties of these layers is limited. High-resolution 3D seismic data and deep boreholes for in-situ logging and sampling for geological and geotechnical data will also contribute to a better characterization of weak layers. High-resolution seismic data are also expected to resolve geological expressions on a meter-scale and provide information related to overpressure and fan morphologies relevant for fluid migration.

Packages of GDFs overlying the glacimarine layer are suggested to act as seals for vertical fluid flow. Glacial sediments trapping fluids below have been observed in other previously glaciated environments (Dumke et al., 2014; Bellwald and Planke, 2018). 

a strong earthquake is the only realistic trigger for a new submarine megaslide at the North Sea TMF.

658

659

660

661

662

663

664

665

666

667

668

669

670

671

672

673

674

675

676

677

678

679

680

This earthquake has probably to be of higher magnitude than what we modeled for the overpressurepreconditioned slope at the time of the Tampen Slide. It is, therefore, fair to state that today's hazard of megasliding and tsunami originating from the North Sea TMF is considerably small, and that it will probably take another interglacial-glacial cycle and/or a strong earthquake to form a situation that would lead to another major landslide on the North Sea TMF.

\section{Conclusions}

In this study we model overpressure and slope stability along the gently-dipping $\left(<1^{\circ}\right)$ North Sea TMF, with the focus to capture stress conditions leading to the development of the Tampen Slide. The influence of sedimentation rate and sediment compressibility on strength reduction on glacial margin submarine slopes has been quantified within the model simulations. However, the results of model simulations should be understood in a qualitative way.

Slope stability has been modeled for a scenario with shelf edge glaciations, ice sheet build-up and ice sheet oscillations during MIS 6, at the end of which the Tampen Slide occurred. As these different configurations result in significant differences in sediment delivery to the study site, we simulate slope stability with different sedimentation patterns, which according to our model result in similar levels of excess pore pressure. Highest overpressure ratios of 0.2 are generated at the interface of an inferred glacimarine layer, when utilizing sedimentation rates of $\sim 4.2 \mathrm{~m} / \mathrm{kyr}$ for the deposition of GDFs during ice-stream maxima. Constant sediment accumulation of $3.3 \mathrm{~m} / \mathrm{kyr}$ results in an overpressure ratio of 0.16. Tests with higher compressibilities of GDFs ( 0.13 instead of 0.10$)$, on the other hand, result in maximum overpressure ratios of 0.55 at the top of an assumed glacimarine layer, which is located below a package consisting of GDFs. As the absence of the glacimarine layer decreases the overpressure ratio, the inherited permeability contrast of this layer is suggested to be fundamental for slope failures to be initiated at the North Sea TMF. The glacimarine layer is suggested to accommodate vertical fluid flow, which is initiated by the rapid deposition of GDFs, which are further acting as a barrier for vertical fluid 
683 flow. The modeling suggests that excess pore pressure alone is not sufficient to destabilize the $\sim 300 \mathrm{~m}$ 684 thick sequence of mainly GDFs, which have been removed by the Tampen Slide. Thus, an earthquake 685 of magnitude M6.9 or larger, close to the Tampen Slide headwall, is suggested to have caused slope 686 failure at the time of the Tampen Slide. Even if such a magnitude event has never been historically documented in Scandinavia, seismicity related to stresses induced by post-glacial isostacy at the time of the Tampen Slide is expected to have been significantly higher than at present, allowing for frequent occurrence of such events.

690 This case study has several implications for TMFs and glaciated margins all over the globe. The model 691 runs showed that overpressure mainly depends on the thickness of sediment overburden, and not on the 692 temporal pattern of glacial deposition. Small changes in the model input parameters, such as 693 compressibility values of glacial sediments, have a big effect on overpressure generation. Geological weak layers seem to be required for megaslides along gently-dipping glaciated margins. However, overpressure alone is not capable of causing failure on these slopes. The modeling suggests that increased seismic activity is the final trigger mechanism for the Tampen Slide. 
$698 \lambda \quad$ logarithmic bulk modulus, "compressibility", dimensionless

$699 \quad \lambda^{*} \quad$ overpressure ratio, dimensionless

$700 \quad v \quad$ Poisson ratio, dimensionless

$701 \Phi_{\text {crit }}$ effective angle of friction, ${ }^{\circ}$, critical angle of friction, shearing resistance

$702 \rho_{\text {dry }} \quad$ dry density, $\mathrm{kg} / \mathrm{m}^{3}$

$703 \sigma_{\mathrm{v}} \quad$ vertical stress, $\mathrm{kPa}$

$704 \sigma_{\mathrm{v}}^{\prime} \quad$ vertical effective stress, $\mathrm{kPa}$

$705 \tau \quad$ shear stress, $\mathrm{kPa}$

$706 \varphi$ friction angle, ${ }^{\circ}$

707 e void ratio, dimensionless

$708 \mathrm{k} \quad$ permeability, $\mathrm{m} / \mathrm{s}$

$709 \mathrm{n} \quad$ porosity, dimensionless

$710 \mathrm{p} \quad$ pore pressure, $\mathrm{kPa}$

$711 \quad \mathrm{p}_{\mathrm{e}} \quad$ excess pore pressure, $\mathrm{kPa}$

$712 \mathrm{p}_{\mathrm{h}} \quad$ hydrostatic pore pressure

713 FoS Factor of safety

$714 \quad \mathrm{~F}_{\text {eq }} \quad$ Earthquake acceleration shear stress parallel to the slope

$715 \quad k_{\text {PSA }} \quad$ Peak spectral acceleration

$716 \mathrm{k}_{\mathrm{y}} \quad$ Critical horizontal earthquake acceleration

\section{Formula}

1) Void ratio

2) Compressibility

3) Overpressure ratio

4) Factor of safety

5) Required earthquake acceleration shear stress parallel to the slope

6) Critical horizontal earthquake acceleration

7) Peak spectral acceleration

$$
\begin{aligned}
& e=\frac{n}{1-n} \\
& \lambda=-\left(\frac{1}{V}\right) \cdot\left(\frac{d V}{d p}\right) \text { and } \lambda=\frac{\ln (p)}{n} \\
& \lambda^{*}=\left(\frac{p-p_{h}}{\sigma_{v}-p_{h}}\right)=\frac{p_{e}}{\sigma^{\prime}{ }_{v}+p_{e}} \\
& F o S=\frac{\sigma_{v}^{\prime} \cdot \tan \phi_{\text {crit }}}{\tau+F_{e q}}
\end{aligned}
$$

$$
F_{e q}=\left(\sigma_{v}^{\prime} \cdot \tan \Phi_{c r i t}\right)-\tau
$$


Acknowledgements: We thank Flavio Anselmetti and David J.W. Piper for thorough discussions and

constructive feedback. The research leading to these results has received funding from the People Programme (Marie Curie Actions) of the European Union's Seventh Framework Programme FP7/20072013/ under REA grant agreement $n^{\circ} 317217$. The research forms part of the GLANAM (GLAciated North Atlantic Margins) Initial Training Network. We are grateful to two anonymous reviewers and Editor Henning Bauch for constructive remarks that helped improve the quality of the manuscript.

\section{References:}

Aksu, A.E., Hiscott, R.N., 1992. Shingled Upper Quaternary debris flow lenses on the NE Newfoundland slope. Sedimentology 39, 193-206.

Batchelor, C.L., Ottesen, D., Dowdeswell, J.A., 2017. Quaternary evolution of the northern North Sea margin through glacigenic debris-flow and contourite deposition. Journal of Quaternary Science 32, 416-426.

Becker, L.W.M., Sejrup, H.P., Hjelstuen, B.O., Haflidason, H., Dokken, T.M., 2018. Ocean-ice sheet interaction along the SE Nordic Seas margin from 35 to15 ka BP. Marine Geology 402, 99-117.

Bellwald, B., Planke, S., 2018. Shear margin moraine, mass transport deposits, and soft beds revealed by high-resolution P-Cable 3D seismic data in the Hoop Area, Barents Sea. Special publication, Geological Society of London.

Berg, K., Solheim, A., Bryn, P., 2005. The Pleistocene to recent geological development of the Ormen Lange area. Marine and Petroleum Geology 22, 45-56.

Bryn, P., Solheim, A., Berg, K., Lien, R., Forsberg, C.F., Haflidason, H., Ottesen, D., Rise, L., 2003. The Storegga Slide complex: repeated large scale sliding in response to climatic cyclicity. In: Locat, J. and Mienert, J. (Eds.), Submarine Mass Movements and Their Consequences, Advances in Natural and Technological Hazard Research, 215-222.

Bryn, P., Berg, K., Forsberg, C.F., Solheim, A., Kvalstad, T.J., 2005. Explaining the Storegga Slide. Marine and Petroleum Geology 22, 11-19. 
Bungum, H., Lindholm, C., Faleide, J.I., 2005. Postglacial seismicity offshore mid-Norway with emphasis on spatio-temporal-magnitudal variations. Marine and Petroleum Geology 22, 137-148.

Bünz, S., Mienert, J., Berndt, C., 2003. Geological controls on the Storegga gas-hydrate system of the mid-Norwegian continental margin. Earth and Planetary Science Letters 209, 291-307.

Byrkjeland, U., Bungum, H., Eldholm, O., 2000. Seismotectonics of the Norwegian continental margin. Journal of Geophysical Research 105, 6221-6236.

Canals, M., Lastras, G., Urgeles, R., Casamor, J.L., Mienert, J., Cattaneo, A., De Batist, M., Haflidason, H., Imbo, Y., Laberg, J.S., Locat, J., Long, D., Longva, O., Masson, D.G., Sultan, N., Trincardi, F., Bryn, P., 2004. Slope failure dynamics and impacts from seafloor and shallow sub-seafloor geophysical data: case studies from the COSTA project. Marine Geology 213, 9-72.

Carlton, B.D., Kaynia, A.M., 2016. Comparison of the Seismic Response of Offshore Slopes Using 1, 2 or 3 Ground Motion Components. Offshore Technology Conference OTC-26961-MS, 1-12.

Dimakis, P., Elverhøi, A., Høeg, K., Solheim, A., Harbitz, C., Laberg, J.S., Vorren, T.O., Marr, J., 2000. Submarine slope stability on high-latitude glaciated Svalbard-Barents Sea margin. Marine Geology $162,303-316$

Dugan, B., Sheahan, T.C., 2012. Offshore sediment overpressures of passive margins: Mechanisms, measurement, and models. Reviews of Geophysics 50, RG3001.

Dumke, I., Berndt, C., Crutchley, G.J., Krause, S., Liebetrau, V., Gay, A., Couillard, M., 2014. Seal bypass at the Giant Gjallar Vent (Norwegian Sea): Indications for a new phase of fluid venting at a 56-Ma-old fluid migration system. Marine Geology 351, 38-52.

Elverhøi, A., Norem, H., Andersen, E.S., Dowdeswell, J.A., Fossen, I., Haflidason, H., Kenyon, N.H., Laberg, J.S., King, E.L., Sejrup, H.P., Solheim, A., Vorren, T., 1997. On the origin and flow behavior of submarine slides on deep-sea fans along the Norwegian-Barents Sea continental margin. GeoMarine Letters 17. 119-125. 
Fischer, D., Mogollón, J.M., Strasser, M., Pape, T., Bohrmann, G., Fekete, N., Spiess, V., Kasten, S., 2013. Subduction zone earthquakes as potential trigger of submarine hydrocarbon seepage. Nature Geoscience 6, 647-651.

Flemings, P.B., Long, H., Dugan, B., Germaine, J., John, C.M., Behrmann, J.H., Sawyer, D., IODP Expedition 308 Scientists, 2008. Pore pressure penetrometers document high overpressure near the seafloor where multiple submarine landslides have occurred on the continental slope, offshore Louisiana, Gulf of Mexico. Earth and Planetary Science Letters 269, 309-325.

Gales, J., Hillenbrand, C.D., Larter, R., Laberg, J.S., Melles, M., Benetti, S., Passchier, S., 2018. Processes influencing differences in Arctic and Antarctic Trough Mouth Fan sedimentology. Geological Society of London, Special Publications.

Gauer, P., Kvalstad, T.J., Forsberg, C.F., Bryn, P., Berg, K., 2005. The last phase of the Storegga Slide: simulation of retrogressive slide dynamics and comparison with slide-scar morphology. Marine and Petroleum Geology 22, 171-178.

Haflidason, H., King, E.L., Sejrup, H.P., 1998. Late Weichselian and Holocene sediment fluxes of the northern North Sea Margin. Marine Geology 152, 189-215.

Haflidason, H., Sejrup, H.P, Berstad, I.M., Nygård, A., Richter, T., Bryn, P., Lien, R., Berg, K., 2003. A Weak Layer Feature on the Northern Storegga Slide Escarpment, in: Mienert, J. et al. (Eds.), European Margin Sediment Dynamics, Springer-Verlag Berlin Heidelberg, 55-62.

Haflidason, H., Lien, R., Sejrup, H.P., Forsberg, C.F., Bryn, P., 2005. The dating and morphology of the Storegga Slide. Marine and Petroleum Geology 22, 123-136.

Hamilton, E.L., 1976. Variations of density and porosity with depth in deep-sea sediments. Journal of Sedimentary Petrology 46, 280-300.

Hampton, M.A., Lee, H.J., Locat, J., 1996. Submarine landslides. Reviews of Geophysics 34, 33-59.

Hiscott, R.N., Aksu, A.E., 1996. Quaternary Sedimentary Processes and Budgets in Orphan Basin, Southwestern Labrador Sea. Quaternary Research 45, 160-175. 
Hjelstuen, B.O., Sejrup, H.P., Haflidason, H., Nygård, A., Berstad, I.M., Knorr, G., 2004. Late Quaternary seismic stratigraphy and geological development of the south Vøring margin, Norwegian Sea. Quaternary Science Reviews 23, 1847-1865.

Hjelstuen, B.O., Sejrup, H.P., Haflidason, H., Nygård, A., Ceramicola, S., Bryn, P., 2005. Late Cenozoic glacial history and evolution of the Storegga Slide area and adjacent slide flank regions, Norwegian continental margin. Marine and Petroleum Geology 22, 57-70.

Hjelstuen, B.O., Eldholm, O., Faleide, J.I., 2007. Recurrent Pleistocene mega-failures on the SW Barents Sea margin. Earth and Planetary Science Letters 258, 605-618.

Hjelstuen, B.O., Nygård, A., Sejrup, H.P., Haflidason, H., 2012. Quaternary denudation of southern Fennoscandia - evidence from the marine realm. Boreas 41, 379-390.

Hjelstuen, B.O., Grinde, S., 2016. 3D Seismic Investigations of Pleistocene Mass Transport Deposits and Glacigenic Debris Flows on the North Sea Fan, NE Atlantic Margin, in: Lamarche, G. et al. (Eds.), Submarine Mass Movements and Their Consequences, Advances in Natural and Technological Hazard research, 265-272.

Hooke, R.L., Elverhøi, A., 1996. Sediment flux from a fjord during glacial periods, Isfjorden, Spitsbergen. Global and Planetary Change 12, 237-249.

Hühnerbach, V., Masson, D., partners of the COSTA-Project, 2004. Landslides in the North Atlantic and its adjacent seas: an analysis of their morphology, setting and behaviour. Marine Geology 213, 343-362.

Jibson, R.W., 2011. Methods for assessing the stability of slopes during earthquakes - A retrospective. Engineering Geology 122, 43-50.

Karig, D.E., Hou, G., 1992. High-stress Consolidation Experiments and Their Geologic Implications. Journal of Geophysical Research 97, 289-300. 
King, E.L., Sejrup, H.P., Haflidason, H., Elverhøi, A., Aarseth, I., 1996. Quaternary seismic stratigraphy of the North Sea Fan: glacially-fed gravity flow aprons, hemipelagic sediments, and large submarine slides. Marine Geology 130, 293-315.

King, E.L., Haflidason, H., Sejrup, H.P., Løvlie, R., 1998. Glacigenic debris flows on the North Sea Trough Mouth Fan during ice stream maxima. Marine Geology 152, 217-246.

Kramer, S.L., 1996. Geotechnical earthquake engineering. Prentice Hall, Upper Saddle River, N.J.

Kratzke, I.C.J., 2018. Testing the effect of ice sheet dynamics on submarine slope stability by means of finite element modeling. Master Thesis, Kiel University, 59 pp.

Kvalstad, T.J., Nadim, F., Kaynia, A.M., Mokkelbost, K.H., Bryn, P., 2005a. Soil conditions and slope stability in the Ormen Lange area. Marine and Petroleum Geology 22, 299-310.

Kvalstad, T.J., Andresen, L., Forsberg, C.F., Berg, K., Bryn, P., Wangen, M., 2005b. The Storegga Slide: evaluation of triggering sources and slide mechanics. Marine and Petroleum Geology 22, 245256.

Laberg, J.S., Vorren, T.O., 1996. The Middle and Late Pleistocene evolution of the Bear Island Trough Mouth Fan. Global Planetary Change 12, 309-330.

Lee, H.J., Locat, J., Dartnell, P., Minasian, D, Wong, F., 2000. A GIS-based regional analysis of the potential for shallow-seated submarine slope failure. Paper presented at $8^{\text {th }}$ International Symposium on Landslides, Br. Geotech Soc., Cardiff, Wales, June 2000, 26-30.

Lee, 2009. Timing and occurrence of large submarine landslides on the Atlantic Ocean margin. Marine Geology 264, 53-64.

Lekens, W.A.H., Sejrup, H.P., Haflidason, H., Petersen, G.Ø., Hjelstuen, B., Knorr, G., 2005. Laminated sediments preceding Heinrich event 1 in the Northern North Sea and Southern Norwegian Sea: Origin, processes and regional linkage. Marine Geology 216, 27-50. 
Leynaud, D., Mienert, J., Vanneste, M., 2009. Submarine mass movements on glaciated and nonglaciated European continental margins: A review of triggering mechanisms and preconditions to failure. Marine and Petroleum Geology 26, 618-632.

L'Heureux, J.S., Vanneste, M., Rise, L., Brendryen, J., Forsberg, C.F., Nadim, F., Longva, O., Chand, S., Kvalstad, T.J., Haflidason, H., 2013. Stability, mobility and failure mechanism for landslides at the upper continental slope off Vesterålen, Norway. Marine Geology 346, 192-207.

Lindholm, C., Roth, M., Bungum, H., Faleide, J.I., 2005. Probabilistic and deterministic seismic hazard results and influence of the sedimentary Møre Basin, NE Atlantic. Marine and Petroleum Geology $22,149-160$.

Llopart, J., Urgeles, R., Camerlenghi, A., Lucchi, R.G., De Mol, B., Rebesco, M., Pedrosa, M.T., 2014. Slope Instability of Glaciated Continental Margins: Constraints from Permeability-Compressibility Tests and Hydrogeological Modeling off Storfjorden, NW Barents Sea. in: Krastel, S. et al., (Eds.), Submarine Mass Movements and Their Consequences, Advances in Natural and Technological Hazard Research 37, 95-104.

Locat, J., Leroueil, S., Locat, A., Lee, H., 2014. Weak Layers: Their Definition and Classification from a Geotechnical Perspective. In: Krastel, S. et al., (Eds.) Submarine Mass Movements and Their Consequences, Advances in Natural and Technological Hazard Research 37, 3-12.

Lucchi, R.G., Pedrosa, M.T., Camerlenghi, A., 2012. Recent submarine landslides on the continental slope of Storfjorden and Kveitehola Trough - Mouth Fans (NW Barents Sea). In: Yamada, Y. et al., (Eds.), Submarine Mass Movements and Their Consequences, Advances in Natural and Technological Hazard Research 31, 735-745.

Maslin, M., Owen, M., Day, S., Long, D., 2004. Linking continental-slope failures and climate change: Testing the clathrate gun hypothesis. Geology 32, 53-56. 
Masson, Harbitz, C.B., Wynn, R.B., Pedersen, G., Løvholt, F., 2006. Submarine landslides: processes, triggers and hazard prediction. Philosophical Transactions. Series A, Mathematical, Physical and Engineering Sciences 364, 2009-2039.

Masson, D.G., Wynn, R.B., Talling, P.J., 2010. Large landslides on passive continental margins: Processes, hypotheses and outstanding questions. In: Mosher, D.C. et al., (Eds.), Submarine Mass Movements and Their Consequences, Advances in Natural and Technological Hazard Research 28, 153-165.

McAdoo, B.G., Pratson, L.F., Orange, D.L., 2000. Submarine landslide geomorphology, US continental slope. Marine Geology 169, 103-136.

Mienert, J., Vanneste, M., Bünz, S., Andreassen, K., Haflidason, H., Sejrup, H.P., 2005a. Ocean warming and gas hydrate stability on the mid-Norwegian margin at the Storegga Slide. Marine and Petroleum Geology 22, 233-244.

Mienert, J., Bünz, S., Guidard, S., Vanneste, M., Berndt, C., 2005b. Ocean bottom seismometer investigations in the Ormen Lange area offshore mid-Norway provide evidence for shallow gas layers in subsurface sediments. Marine and Petroleum Geology 22, 287-297.

Morgenstern, N.R., 1967. Submarine slumping and the initiation of turbidity currents. In: Richards, A.F. (Ed.), Marine Geotechnique. University of Illinois Press, Urbana, IL, 189-210.

Nygård, A., Sejrup, H.P., Haflidason, H., King, E.L., 2002. Geometry and genesis of glacigenic debris flows on the North Sea Fan: TOBI imagery and deep-tow boomer evidence. Marine Geology 188, $15-33$.

Nygård, A., Sejrup, H.P., Haflidason, H., Bryn, P., 2005. The glacial North Sea Fan, southern Norwegian Margin: architecture and evolution from the upper continental slope to the deep-sea basin. Marine and Petroleum Geology 22, 71-84. 
Nygård, A., Sejrup, H.P., Haflidason, H., Lekens, W.A.H., Clark, C.D., Bigg, G.R., 2007. Extreme sediment and ice discharge from marine-based ice streams: New evidence from the North Sea. Geology 35, 395-398.

Owen, M., Day, S., Maslin, M., 2007. Late Pleistocene submarine mass movements: occurrence and causes. Quaternary Science Reviews 7-8, 958-978.

Pezeshk, S., Zandieh, A., Campbell, K.W. and Tavakoli, B., 2015. Ground-Motion Prediction Equations for CENA Using the Hybrid Empirical Method in Conjunction with NGA-West2 Empirical GroundMotion Models, in Pacific Earthquake Engineering Research Center (PEER), NGA-East: Median Ground-Motion Models for the Central and Eastern North America Region, PEER Report No. 2015/04, $351 \mathrm{pp}$.

Piper, D.J.W., Mosher, D.C., Gauley, B.J., Jenner, K., Campell, D.C., 2003. The chronology and recurrence of submarine mass movements on the continental slope off southeastern Canada. In: Locat, J. and Mienert, J. (Eds.), Submarine Mass Movements and Their Consequences, Advances in Natural and Technological Hazard Research, 299-306.

Piper, D.J.W., 2014. Process, time and architecture: lessons from slope contourites and their failures in the path of the Labrador Current. $2^{\text {nd }}$ Deep-Water Circulation Congress, Ghent, Belgium, September 2014, 3-4.

Pope, E.L., Talling, P.J., Carter, L., 2017. Which earthquakes trigger damaging submarine mass movements: Insights from a global record of submarine cable breaks? Marine Geology 384, 131146.

Pope, E.L., Talling, P.J., O'Cofaigh, C., 2018. The relationship between ice sheets and submarine mass movements in the Nordic Seas during the Quaternary. Earth-Science Reviews 178, 208-256.

Rebesco, M., Laberg, J.S., Pedrosa, M.T., Camerlenghi, A., Lucchi, R.G., Zgur, F., Wardell, N., 2013. Onset and growth of Trough-Mouth Fans on the North-Western Barents Sea margin - implications for the evolution of the Barents Sea/Svalbard Ice Sheet. Quaternary Science Reviews 92, 227-234. 
Riis, F., Berg, K., Cartwright, J., Eidvin, T., Hansch, K., 2005. Formation of large, crater-like evacuation structures in ooze sediments in the Norwegian Sea. Possible implications for the development of the Storegga Slide. Marine and Petroleum Geology 22, 257-274.

Schneider, J., Flemings, P.B., Dugan, B., Long, H., Germaine, J.T., Overpressure and consolidation near the seafloor of Brazos-Trinity Basin IV, northwest deepwater Gulf of Mexico. Journal of Geophysical Research 114, B05102.

Sejrup, H.P., King, E.L., Aarseth, I., Haflidason, H., Elverhøi, A., 1996. Quaternary erosion and depositional processes: western Norwegian fjords, Norwegian Channel and North Sea Fan. Geological Society Special Publication 117, 187-202.

Sejrup, H.P., Larsen, E., Haflidason, H., Berstad, I.M., Hjelstuen, B.O., Jonsdottir, H., King, E.L., Landvik, J., Longva, O., Nygård, A., Ottesen, D., Raunholm, S., Rise, L., Stalsberg, K., 2003. Configuration, history and impact of the Norwegian Channel Ice Stream. Boreas 32, 18-36.

Sejrup, H.P., Haflidason, H., Hjelstuen, B.O., Nygård, A., Bryn, P., Lien, R., 2004. Pleistocene development of the SE Nordic Seas margin. Marine Geology 213, 169-200.

Sejrup, H.P., Hjelstuen, B.O., Dahlgren, K.I.T., Haflidason, H., Kuijpers, A., Nygård, A., Praeg, D., Stoker, M.S., Vorren, T.O., 2005. Pleistocene glacial history of the NW European continental margin. Marine and Petroleum Geology 22, 1111-1129.

Skene, K.I., Piper, D.J.W., Aksu, A.E., Syvitski, J.P.M., 1998. Evaluation of the global oxygen isotope curve as a proxy for Quaternary sea level by modeling of delta progradation. Journal of Sedimentary Research 68, 1077-1092.

Solheim, A., Bryn, P., Sejrup, H.P., Mienert, J., Berg, K., 2005. Ormen Lange - an integrated study for the safe development of a deep-water gas field within the Storegga Slide Complex, NE Atlantic continental margin; executive summary. Marine and Petroleum Geology 22, 1-10.

Stigall, J., Dugan, B., 2010. Overpressure and earthquake initiated slope failure in the Ursa region, northern Gulf of Mexico. Journal of Geophysical Research 115, 167-178. 
Stoecklin, A., Friedli, B., Puzrin, A.M., 2017. Sedimentation as a control for large submarine landslides - mechanical modelling and analysis of the Santa Barbara basin. Journal of Geophysical Research $122(11), 8645-8663$.

Strout, J.M., Tjelta, T.I., 2005. In situ pore pressures: what is their significance and how can they be reliably measured? Marine and Petroleum Geology 22, 275-286.

Swarbrick, R.E., Osborne, M.J., 1998. Mechanisms that Generate Abnormal Pressures: an Overview. In: Law, B.E. et al. (Eds.), AAPG Memoir 70, 13-34.

ten Brink, U.S., Lee, H.J., Geist, E.L., Twichell, D., 2009. Assessment of tsunami hazard to the U.S. East Coast using relationships between submarine landslides and earthquakes. Marine Geology 264, 65-73.

ten Brink, U.S., Andrews, B.D., Miller, N.C., 2016. Seismicity and sedimentation rate effects on submarine slope stability. Geology 44, 563-566.

Tishchenko, P., Hensen, C., Wallmann, K., Wong, C.S., 2005. Calculation of the stability and solubility of methane hydrate in seawater. Chemical Geology 219, 37-52.

Tripsanas, E.K., Piper, D.J.W., Campell, C., 2008. Evolution and depositional structure of earthquakeinduced mass movements and gravity flows: Southwest Orphan Basin, Labrador Sea. Marine and Petroleum Geology 25, 645-662.

Twichell, D.C., Chaytor, J.D., ten Brink, U.S., Buczkowski, B., 2009. Morphology of late Quaternary submarine landslides along the U.S. Atlantic continental margin. Marine Geology 264, 4-15.

Urgeles, R., Camerlenghi, A., 2013. Submarine landslides of the Mediterranean Sea: Trigger mechanisms, dynamics, and frequency-magnitude distribution. Journal of Geophysical Research $118,2600-2618$.

Urlaub, M., Zervos, A., Talling, P.J., Masson, D.G., Clayton, C.I., 2012. How do $2^{\circ}$ slopes fail in areas of slow sedimentation? A sensitivity study on the influence of accumulation rate and permeability 

Consequences, Advances in Natural and Technological Hazard Research 31, 277-287.

972 Urlaub, M., Talling, P.J., Zervos, A., Masson, D., 2015. What causes large submarine landslides on low gradient $\left(<2^{\circ}\right)$ continental slopes with slow $(\sim 0.15 \mathrm{~m} / \mathrm{kyr})$ sediment accumulation? Journal of Geophysical Research: Solid Earth 120, 6722-6739.

975

976

977

978

979

980

981

982

983

984

985

986

987

988

989

990

991

992

993

Urlaub, M., Geersen, J., Krastel, S., Schwenk, T., 2018. Diatom ooze: Crucial for the generation of submarine mega-slides? Geology 46, 331-334.

Vanneste, M., Sultan, N., Garziglia, S., Forsberg, C.F., L’Heureux, J.S., 2014. Seafloor instabilities and sediment deformation processes: The need for integrated, multi-disciplinary investigations. Marine Geology 352, 183-214.

Vanneste, M., L'Heureux, J.S., Baeten, N., Brendryen, J., Vardy, M.E., Steiner, A., Forsberg, C.F., Kvalstad, T.J., Laberg, J.S., Chand, S., Longva, O., Rise, L., Haflidason, H., Hjelstuen, B.O., Forwick, M., Morgan, E., Lecomte, I., Kopf, A., Vorren, T.O., Reichel, T., 2012. Shallow Landslides and Their Dynamics in Coastal and Deepwater Environments, Norway. In: Yamada, Y. et al., (Eds.), Submarine Mass Movements and Their Consequences, Advances in Natural and Technological Hazard Research 31, 29-41.

Vorren, T.O., Laberg, J.S., 1997. Trough mouth fans - paleoclimate and ice-sheet monitors. Quaternary Science Reviews 16, 865-881.

Vorren, T.O., Laberg, J.S., Blaume, F., Dowdeswell, J.A., Kenyon, N.A., Mienert, J., Rumohr, J., Werner, F., 1998. The Norwegian-Greenland sea continental margins: morphology and late Quaternary sedimentary processes and environment. Quaternary Science Reviews 17, 273-302.

www.skjelv.no, Norwegian National Seismic Network, Bergen, Norway, 15.08.2016

www.vectorworldmap.com, Vector World Map, Graphics Factory CC, Pretoria, South Africa, 15.08.2016. 


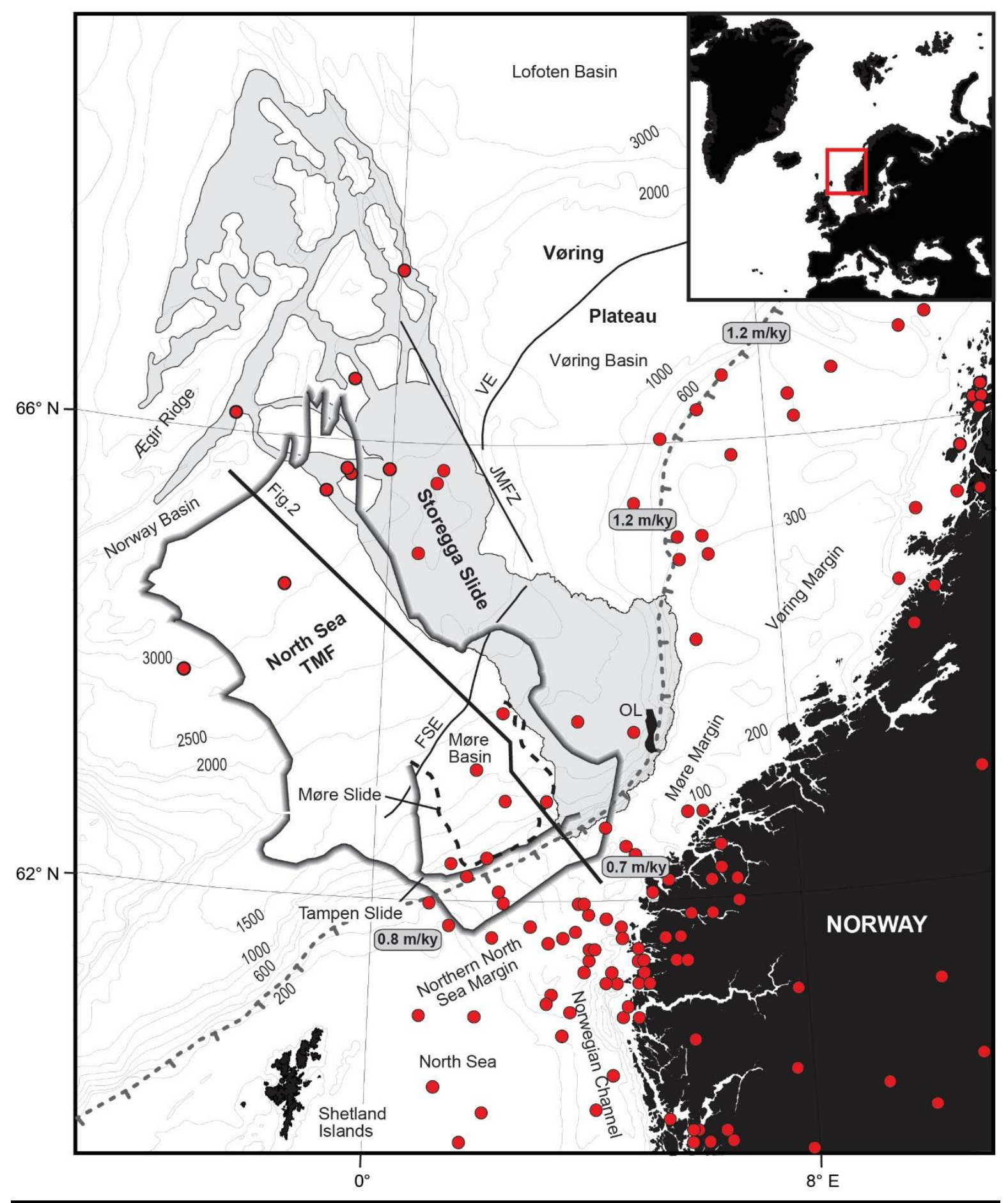

Fig. 1. The Norwegian continental margin with outline of identified submarine slides and the North Sea trough mouth fan (TMF). Stippled gray line indicates maximum ice sheet extent during the Last Glacial Maximum (Sejrup et al., 2016) and numbers in gray boxes indicate subsidence rates (Sejrup et al., 2004). Earthquakes with magnitudes $M>4$ since 1970 are shown (Norwegian National Seismic Network, www.skjelv.no). FSE: Faroe-Shetland Escarpment, JMFZ: Jan Mayen Fracture Zone, OL: Ormen Lange gas field, VE: Vøring Escarpment. World map from www.vectorworldmap.com. 


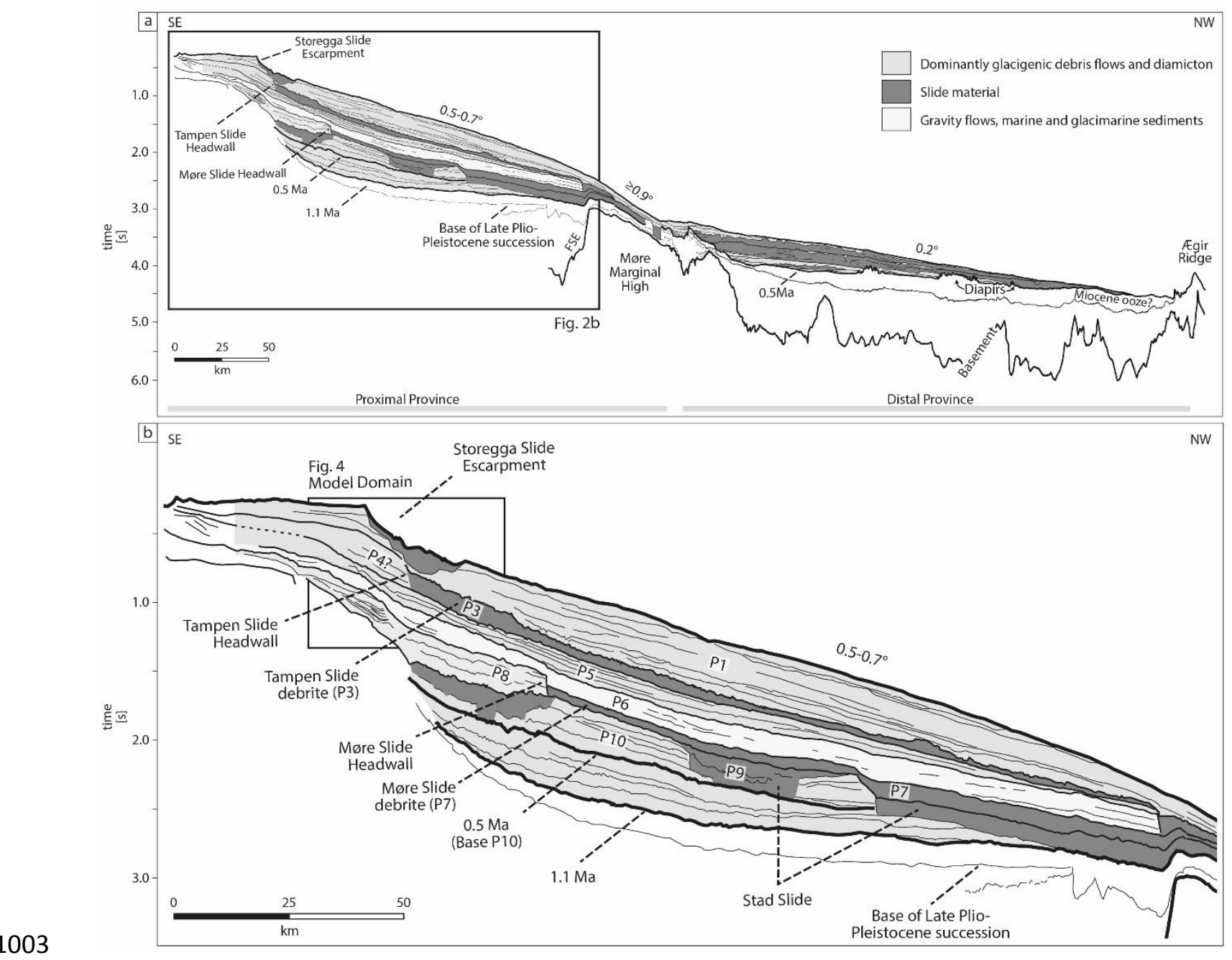

Fig. 2. a) Interpreted seismic profile across the North Sea TMF (modified after Nygård et al., 2005 and Hjelstuen et al., 2012). Seismostratigraphic units (P1-P10) and identified time horizons are indicated. Profile location in Fig. 1. FSE: Faroe-Shetland Escarpment, b) Blow-up of the proximal province of the North Sea TMF. 


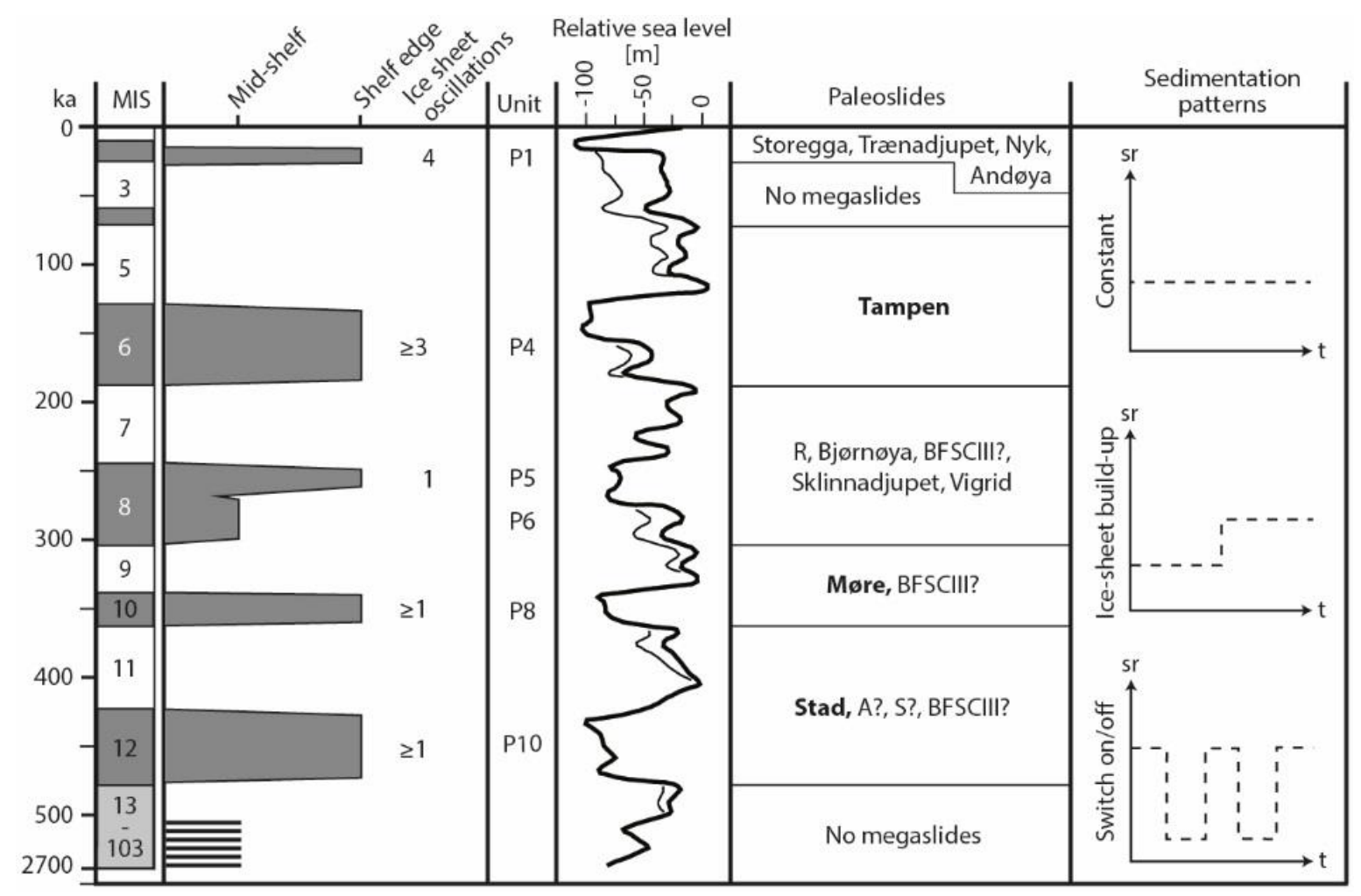

1010 Fig. 3. Assumed shelf edge glaciations of the Norwegian Channel Ice Stream during the past $500 \mathrm{ka}$ 1011 (modified after Nygård et al., 2005). Seismic units (P1-P10), relative sea level curve (Skene et al., 1998), 1012 paleoslides identified along the Norwegian-Barents Sea margin (summarized by Hjelstuen et al., 2007) 1013 and sedimentation patterns used in the different model runs of this study are shown. Slides on the North 1014 Sea TMF are indicated in bold. Shelf-edge glaciations dominate the late Quaternary sedimentation, 1015 whereas a different ice-sheet configuration is documented in early and mid-Quaternary (Batchelor et al., 1016 2017). MIS: Marine isotope stage, sr: Sedimentation rate, t: Time. 


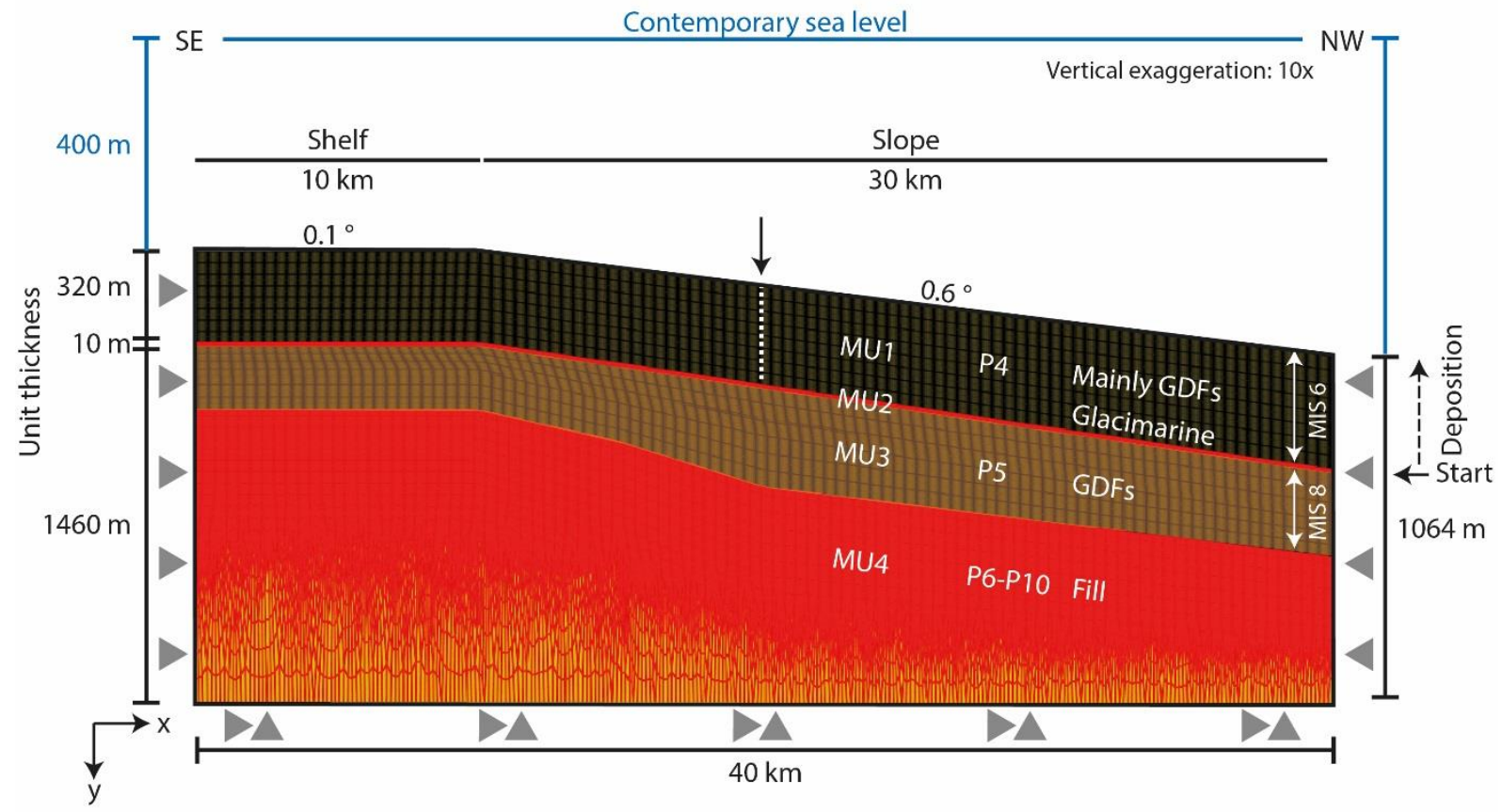

1019 Fig. 4. Two-dimensional model geometry for the time of the Tampen Slide (130 ka BP) reconstructed based on the identified seismic sequences P4-P10 of Nygård et al. (2005). Headwall of the Tampen Slide (white stippled line) and thin glacimarine layer (red line) are shown. Black arrow indicates location of 1022 the profiles for the model output parameters (Figs. 7-9). Triangles indicate displacement boundary 1023 conditions. The model simulations start with the deposition of eight rows of MU1. GDF: Glacigenic 1024 debris flow. MU: Model unit. 

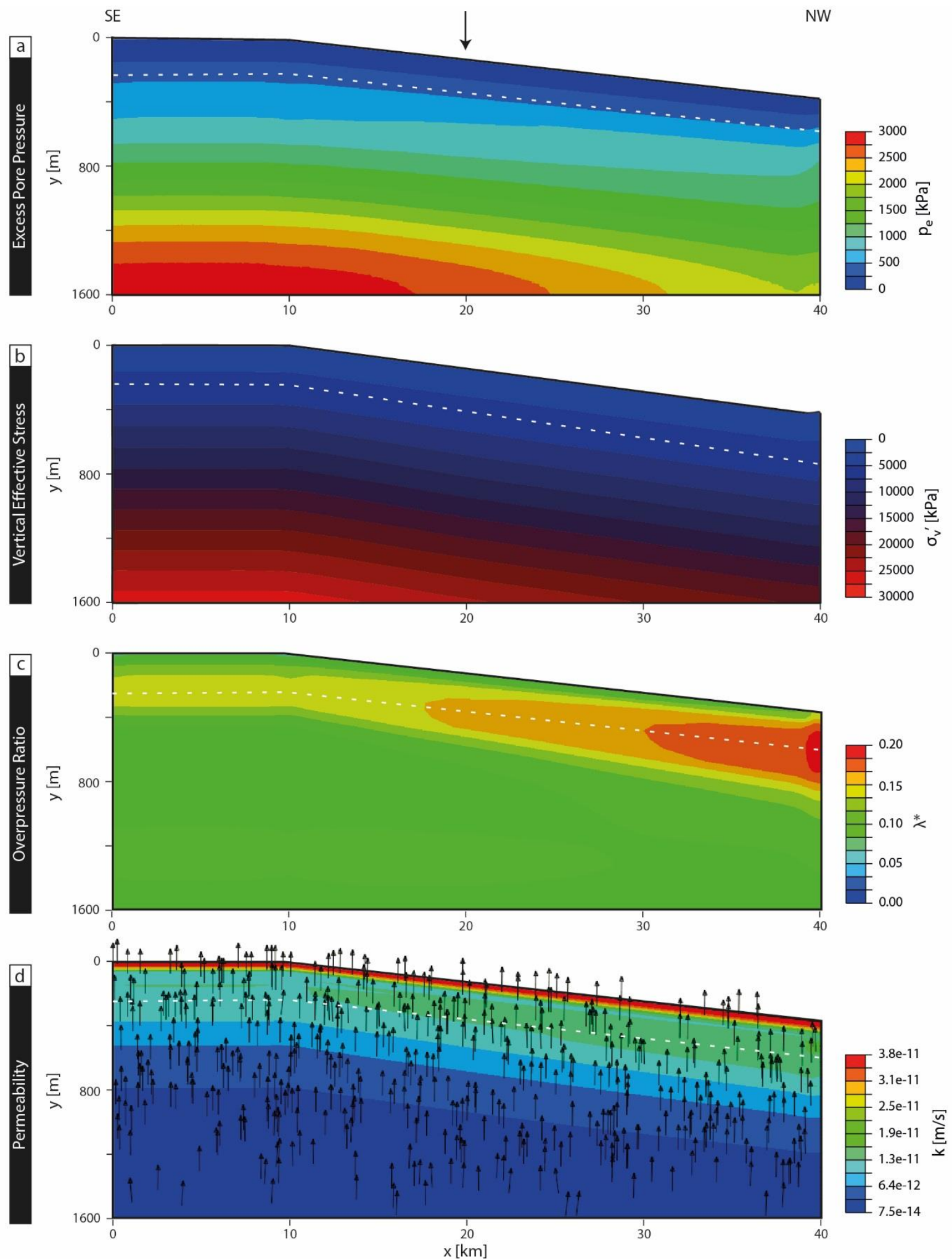

Fig. 5. Results of 2D FE consolidation analysis for the reference model run after deposition of MU1.

White stippled line indicates location of glacimarine layer (MU2) and black arrow show the position of the Tampen Slide headwall. Note a vertical exaggeration of 10 . Vectors in the permeability plot are randomly selected, and only show the direction of fluid flow, but not the magnitude. 

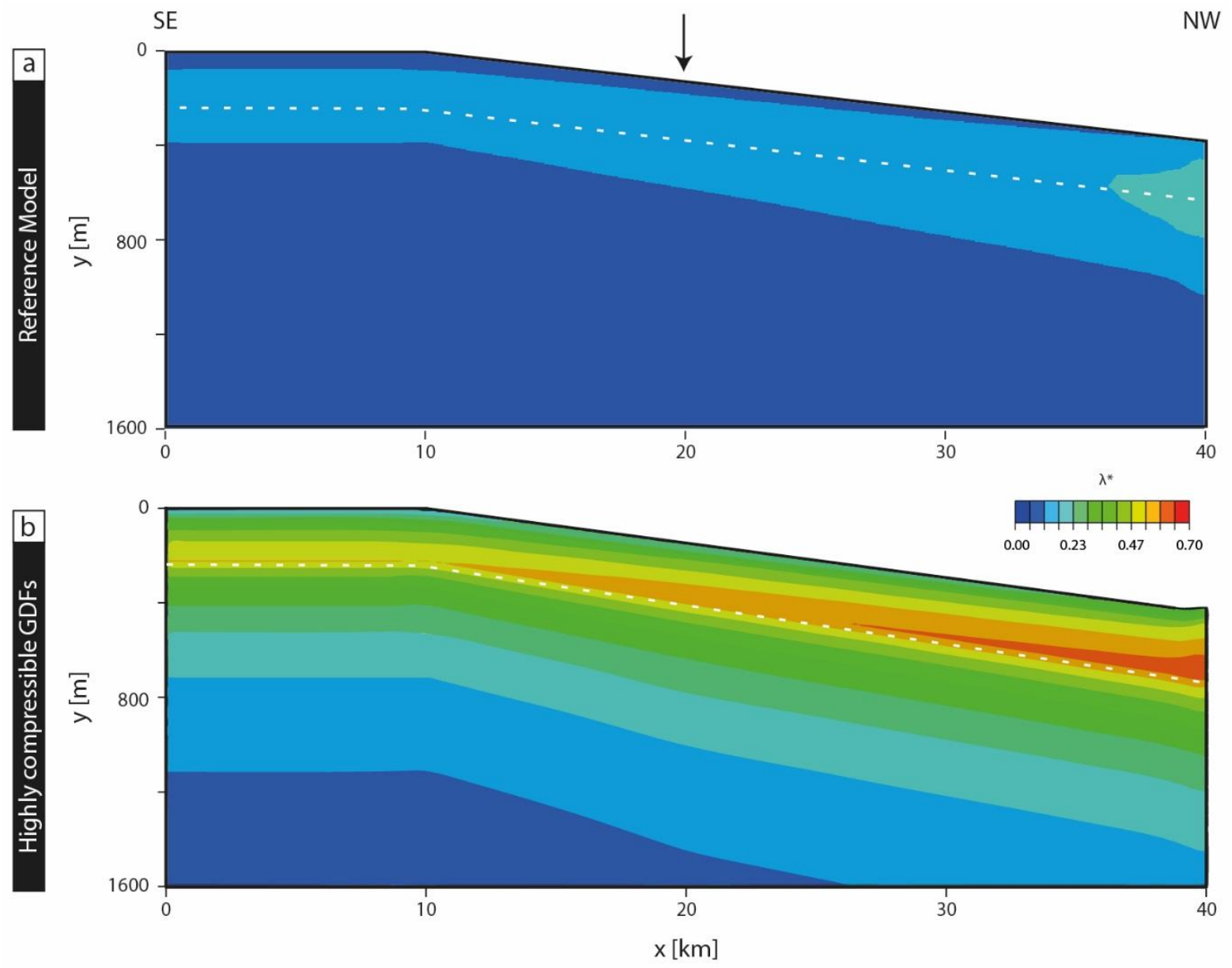

1033 Fig. 6. Comparison of overpressure ratio for different compressibilities ( $\lambda$ ) in MU1 at the end of MIS 6. 1034 a) Reference model with $\lambda=0.10, \mathbf{b})$ Reference model with $\lambda=0.13$. 


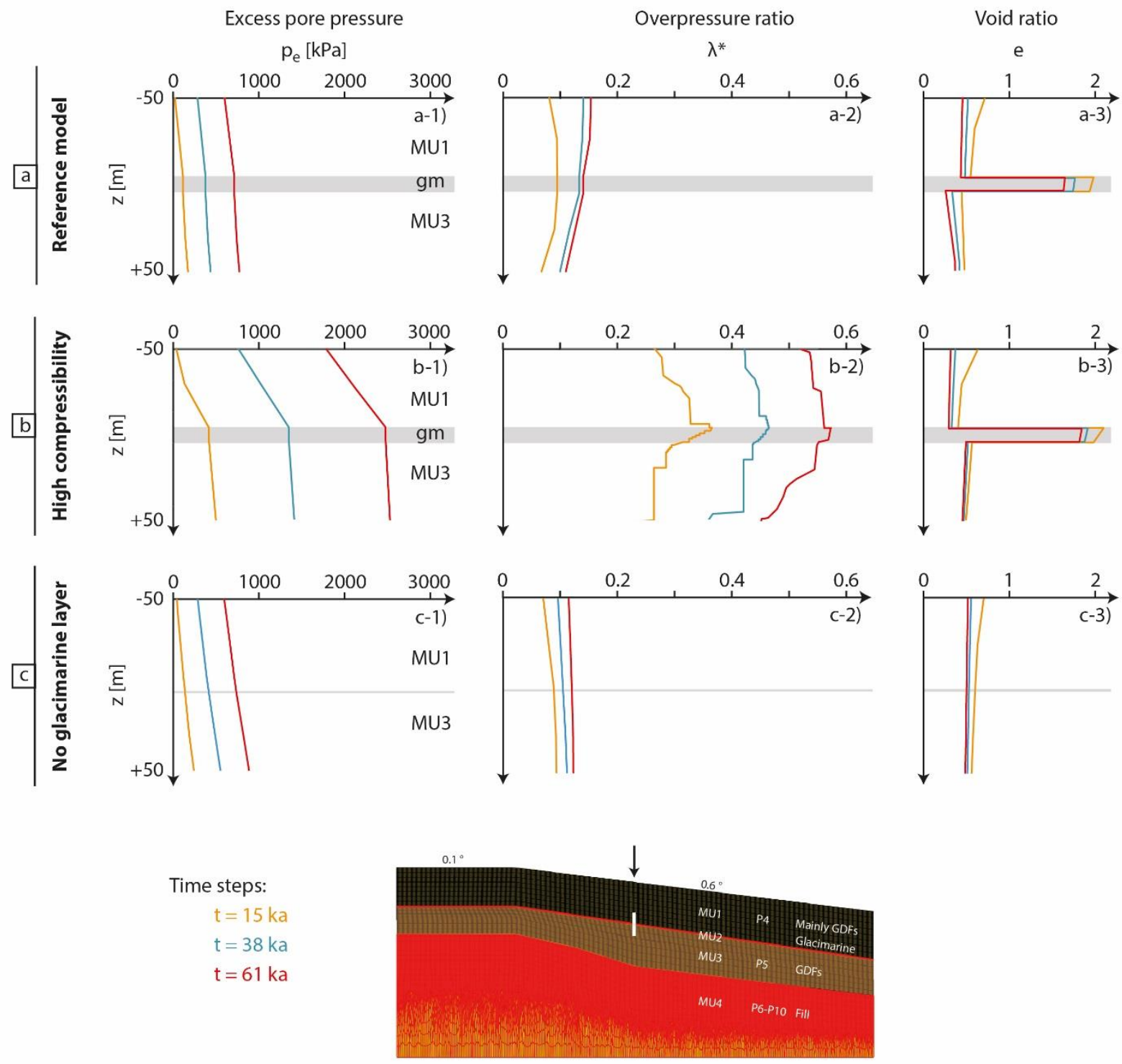

1037 Fig. 7. Vertical profiles visualizing the effect of the glacimarine layer on slope stability. Vertical profiles $1038 \pm 50 \mathrm{~m}$ of the glacimarine layer at $\mathrm{x}=20 \mathrm{~km}$ (white bar) are shown for several simulation time steps 1039 represented by different colors. Color coding as well as location of vertical profiles in the model domain 1040 are given at the bottom of the figure. The profiles show the evolution in time of excess pore pressure $1041\left(\mathrm{p}_{\mathrm{e}}\right)$, overpressure ratio $\left(\lambda^{*}\right)$ and void ratio (e). 


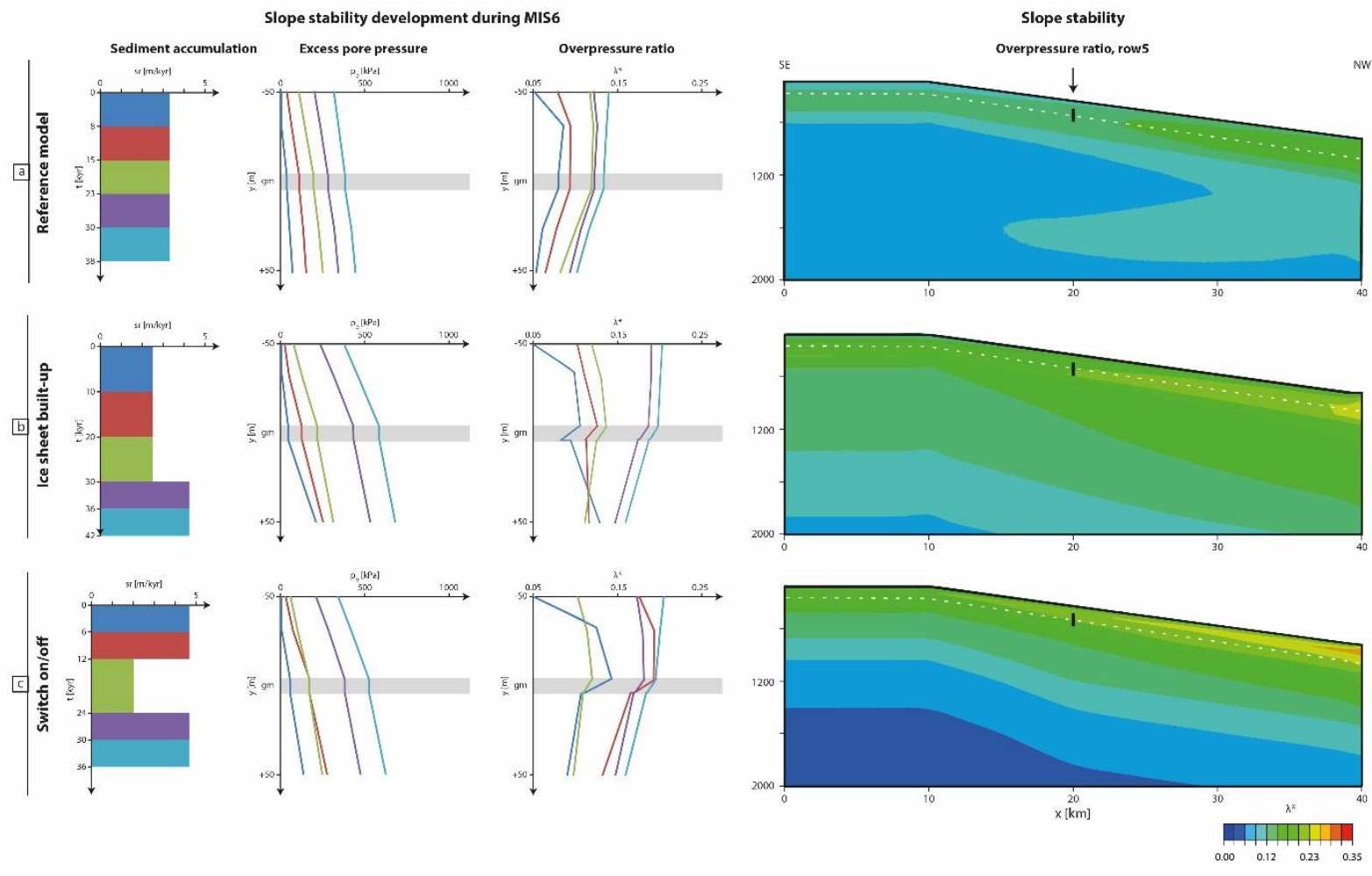

1044 Fig. 8. Vertical profiles $\pm 50 \mathrm{~m}$ of the glacimarine layer for the three sedimentation patterns showing the evolution in time (different colors representing different time steps) of excess pore pressure $\left(\mathrm{p}_{\mathrm{e}}\right)$ and overpressure ratio $\left(\lambda^{*}\right)$. Results of 2D FE consolidation analysis are shown to the right. a) Model run with constant sediment load, b) Model run with variable sediment load, c) Model run with episodic sediment load. 


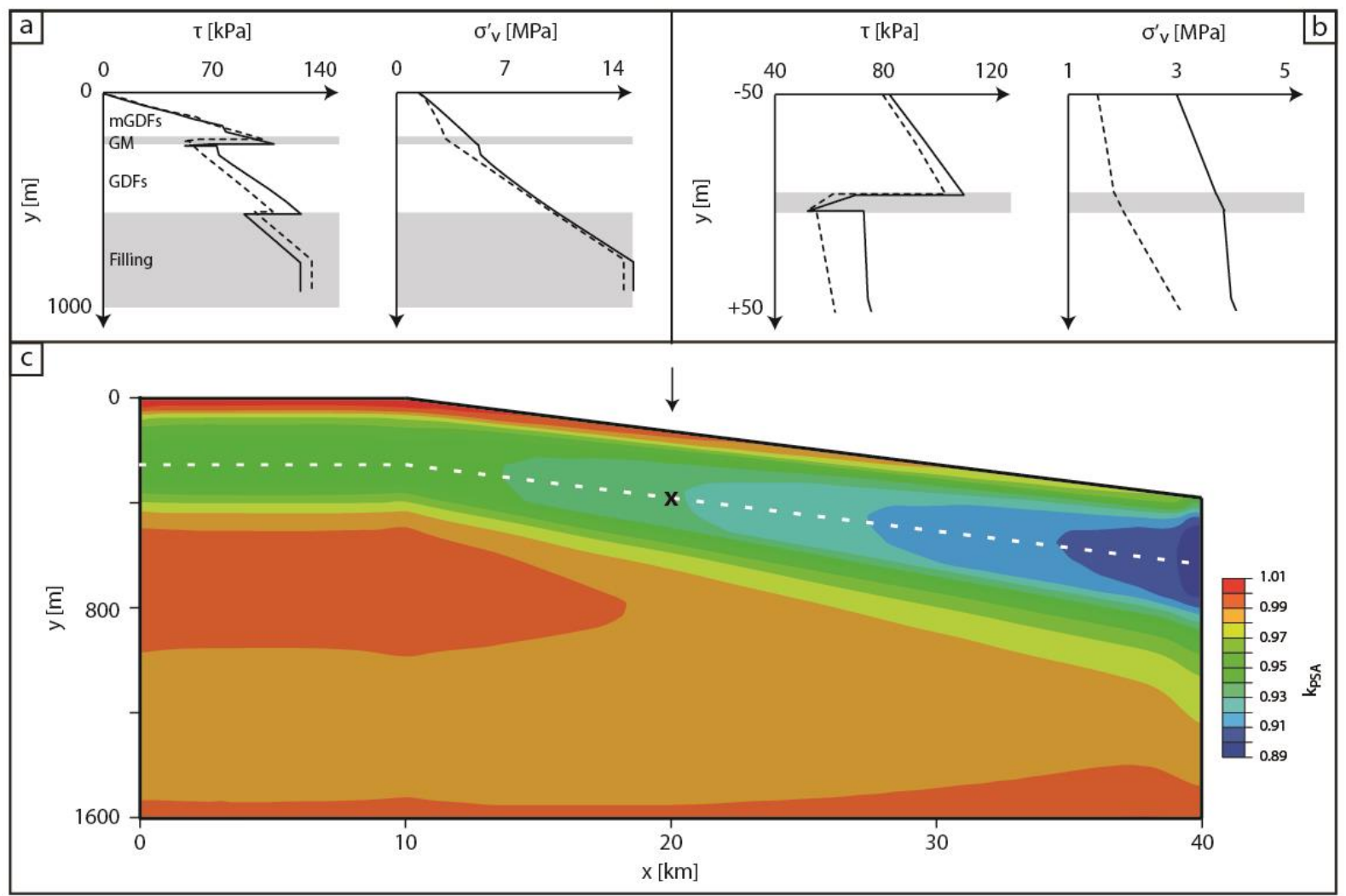

Fig. 9. a) Vertical profiles for shear stress $\tau$ and vertical effective stress $\sigma^{\prime}{ }_{v}$. We assume that the slope will fail at the depth with highest shear stresses and lowest vertical effective stresses, which correlates with the glacimarine layer (GM). Results of the reference model with measured compressibilities (black line) and high-compressible layer mainly consisting of GDFs (stippled line) are indicated. b) Blow-up along the expected location of slope failure. c) Peak spectral acceleration $\left(\mathrm{k}_{\mathrm{PSA}}\right)$ of the 2D FE consolidation analysis for the reference model run with measured sediment properties at the age of the Tampen Slide ( $\mathrm{t}=130 \mathrm{ka} \mathrm{BP}$ ). White stippled line indicates location of glacimarine layer (MU2), black arrow show the position of Tampen Slide headwall and the black cross the expected point of slope failure. 


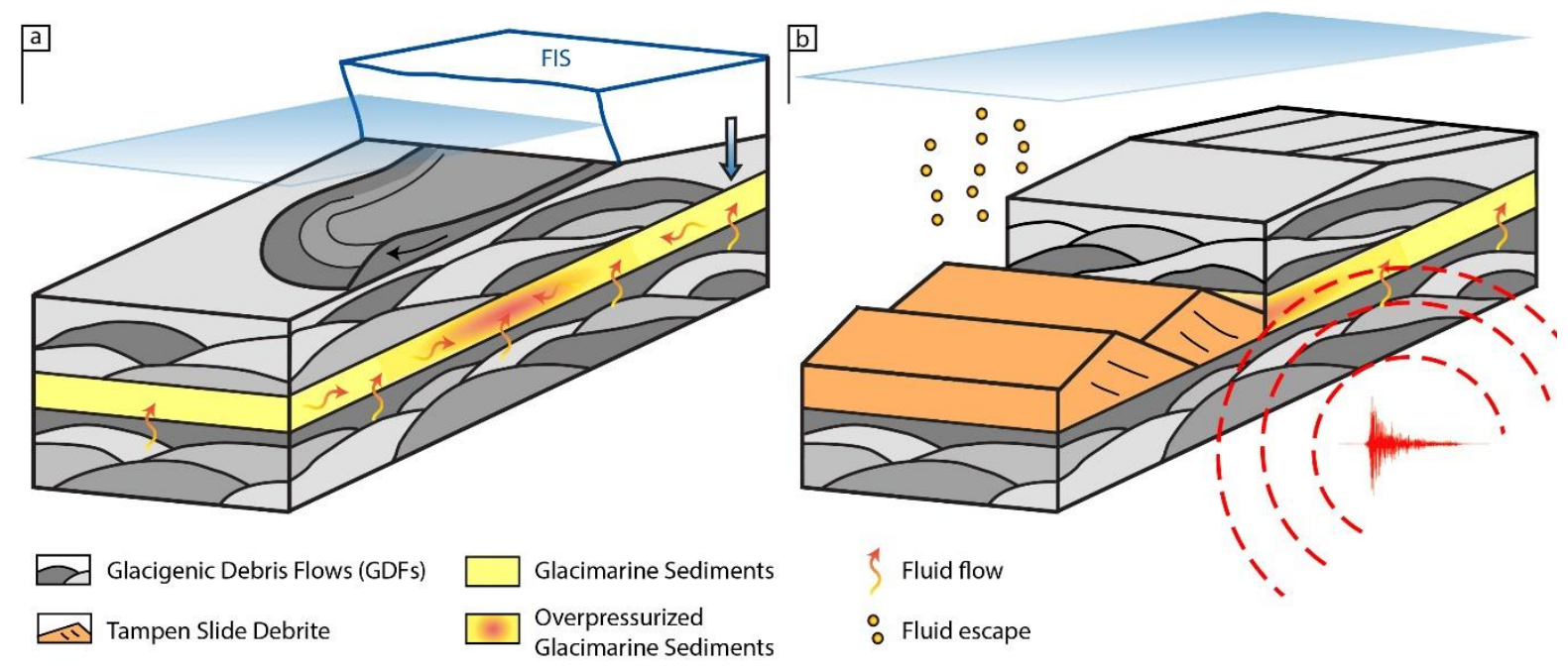

Fig. 10. Conceptual sketch showing preconditioning and triggering of the Tampen Slide. a) Glacigenic debris flows are common sedimentary processes during the MIS 6 shelf edge glaciations of the Fennoscandian Ice Sheet (FIS). Numerous sequences of stacked and rapidly-deposited glacigenic debris flows act as a seal for vertical fluid flow, and fluids accumulate in the glacimarine layer. The highest overpressure ratios are generated c. $10 \mathrm{~km}$ away from the shelf edge, where the sediment accumulation is highest. b) A earthquake of M6.9 or larger at a short distance from the Tampen Slide headwall trigger the Tampen Slide at the location where highest overpressure values have been generated. The glacimarine layer can only be identified upslope of the Tampen Slide headwall, where it still might be overpressured. 
Tab. 1. Model Units (MU) of this study. Thicknesses, P-wave velocities and ages according to Nygård et al. (2005). Thicknesses in ms as observed in seismic profiles; thicknesses in $\mathrm{m}$ inferred from P-wave velocities; CSU: Corresponding seismic unit after Nygård et al. (2005), GDFs: Glacigenic debris flows, GMs: Glacimarine sediments, GFs: Gravity flows, MIS: Marine isotope stage, x: undefined.

\begin{tabular}{ccccccccc}
\hline MU & CSU & Sediment type & $\begin{array}{c}\text { Thickness } \\
{[\mathbf{m s}]}\end{array}$ & $\begin{array}{c}\text { Thickness } \\
{[\mathbf{m}]}\end{array}$ & $\begin{array}{c}\text { P-wave } \\
{[\mathbf{m} / \mathbf{s}]}\end{array}$ & $\begin{array}{c}\text { Time } \\
{[\mathbf{k a}]}\end{array}$ & Age & $\begin{array}{c}\text { Relative } \\
\text { sedimentation }\end{array}$ \\
\hline $\mathbf{1 + 2}$ & P4 & Mainly GDFs & 259 & 246 & 1900 & 113 & MIS 6 & High \\
$\mathbf{1}$ & P4 & Mainly GDFs & $\mathrm{x}$ & 236 & $\mathrm{x}$ & 61 & MIS 6 & High \\
$\mathbf{2}$ & P4 & GMs/GFs & $\mathrm{x}$ & 10 & $\mathrm{x}$ & 52 & MIS 7-8 & Moderate \\
$\mathbf{3}$ & P5 & GDFs & 74 & 63 & 1900 & 57 & MIS 8 & High \\
$\mathbf{4}$ & P6-P10 & Fill & $\mathrm{x}$ & $\mathrm{x}$ & $\mathrm{x}$ & 178 & MIS 9-12 & Low-High \\
\hline
\end{tabular}

Tab. 2. Sediment properties of the material used in the modeling. Geotechnical correlations established by NGI (Kvalstad et al., 2005a).

\begin{tabular}{lccc}
\hline & Glacial debris & Mainly glacial debris & (Glaci)-marine sediments \\
\hline Poisson ratio, $\boldsymbol{v}$ & 0.3 & 0.3 & 0.3 \\
Friction angle, $\boldsymbol{\varphi}\left[{ }^{\circ}\right]$ & 28 & 28 & 28 \\
Dry density, $\mathbf{\rho d r y}\left[\mathbf{k g} / \mathbf{m}^{\mathbf{3}}\right]$ & 2.0 & 2.0 & 1.8 \\
Void ratio, $\mathbf{e} 0$ & 1.2 & 1.2 & 3.5 \\
Compressibility*, $\boldsymbol{\lambda}$ & $0.04-0.17$ & 0.1 & $0.13-0.57$ \\
& $(\mathrm{e} \rightarrow 0.08-1.2)$ & & $(\mathrm{e} \rightarrow 0.25-2.77)$ \\
\hline
\end{tabular}

*Logarithmic bulk modulus; void-ratio dependent

Tab. 3. Model scenarios. Compressibility $(\lambda)$, permeability $(\mathrm{k})$ and void ratio (e) defined in Tab. 3. A: $3.3 \mathrm{~m} / \mathrm{ka}, \mathrm{B}: 2.5 \mathrm{~m} / \mathrm{ka}, \mathrm{C}: 4.2 \mathrm{~m} / \mathrm{ka}$, D: $2.1 \mathrm{~m} / \mathrm{ka}$. GM: Glacimarine sediments, GDFs: Glacigenic debris flows, MGDF: Mainly glacigenic debris flows, $\mathrm{k}_{\mathrm{x}}$ : Horizontal permeability, $\mathrm{k}_{\mathrm{y}}$ : Vertical permeability. Consolidation properties based on geotechnical analyses of sediments from the Ormen Lange area (NGI, Kvalstad et al., 2005b).

\begin{tabular}{lcccccc}
\hline & $\begin{array}{c}\text { Time } \\
{[\mathbf{k a}]}\end{array}$ & $\begin{array}{c}\text { Sedimentation } \\
\text { rate }\end{array}$ & $\boldsymbol{\lambda}_{\text {GM }}$ & $\boldsymbol{\lambda}_{\text {GDF }}$ & $\boldsymbol{\lambda}_{\text {MGDF }}$ & $\mathbf{k}_{\mathbf{x}} / \mathbf{k}_{\mathbf{y}}$ \\
\hline Reference Model & 61 & $\mathrm{~A}$ & Tab. 2 & Tab. 2 & 0.1 & 1 \\
Reference Model, high compressibility & 61 & $\mathrm{~A}$ & Tab. 2 & Tab. 2 & 0.13 & 1 \\
Reference Model, no glacimarine layer & 61 & $\mathrm{~A}$ & Tab. 2 & Tab. 2 & 0.1 & 1 \\
Reference Model, 5 rows & 38 & $\mathrm{~A}$ & Tab. 2 & Tab. 2 & 0.1 & 1 \\
Ice-sheet built-up, 5 rows & 42 & B/C & Tab. 2 & Tab. 2 & 0.1 & 1 \\
Switch on/off, 5 rows & 36 & C/D/C & Tab. 2 & Tab. 2 & 0.1 & 1 \\
\hline
\end{tabular}

